\title{
Do Parents' Social Skills Influence Their Children's Sociability?*
}

\author{
Tsunao Okumura ${ }^{\dagger}$ \\ Emiko Usui ${ }^{\ddagger}$ \\ Yokohama National University \\ Nagoya University and IZA
}

\begin{abstract}
This paper examines the effect of parents' social skills on children's sociability, using the U.S. National Longitudinal Survey of Youth 1979 (NLSY79). This survey, like some other national surveys, lacks detailed information on parents; to remedy this deficiency, we construct a measure of parents' "sociability" skills based on their occupational characteristics from the Dictionary of Occupational Titles (DOT). The sociability relationship varies across parents and children by gender, but remains statistically significant (especially between fathers and sons), even after controlling for a variety of other background characteristics.
\end{abstract}

JEL Classification: J24; J62.

Keywords: Sociability; Intergenerational correlations; Occupational characteristics.

${ }^{*}$ For helpful comments we thank Joseph Altonji, Sheng-Kai Chang, Seik Kim, Hideo Owan, and participants in meetings held at Hitotsubashi University, Hokkaido University, Oakland University, Osaka University, Tohoku University, the Trans-Pacific Labor Seminar, and the University of Michigan, and in the annual meetings of the North American Econometric Society, the European Association of Labour Economists, the Japanese Economic Association, and the Society of Labor Economists. Errors are our own. This paper was initially part of a longer paper, "Intergenerational Correlations of Skills," which has since splintered into separate papers. This research is supported by JSPS grant 22000001 (Usui).

${ }^{\dagger}$ Tsunao Okumura, International Graduate School of Social Sciences, Yokohama National University, Yokohama, 240-8501, Japan. Tel and fax: +81-45-339-3524. E-mail address: okumura@ynu.ac.jp.

${ }^{\ddagger}$ Corresponding author: Emiko Usui, Graduate School of Economics, Nagoya University, Nagoya, 464-8601, Japan. Tel and fax: +81-52-789-4940. E-mail address: usui@soec.nagoya-u.ac.jp. 


\section{Introduction}

Several studies indicate that social skills (e.g., in communication, interpersonal interactions, and leadership) are important determinants of labor market outcomes. Kuhn and Weinberger (2005) find positive returns to occupying leadership positions in high school, especially in managerial occupations. Borghans, ter Weel, and Weinberg (2006) show that people who are sociable early in life are more likely to hold jobs in which people tasks are important, and that returns to people skills are greater in these jobs. Machin, McIntosh, Vignoles, and Viitanen (2001) find positive labor market returns to sociability for U.K. men. While the predictive power of social skills on labor market outcomes has been studied using large population samples, less has been done on studying the link in sociability between parent and child.

Studying the intergenerational link in social skills has been difficult because data on parents' social skills are lacking. ${ }^{1}$ Nationally representative surveys, such as the National Longitudinal Survey of Youth 1979 (NLSY79), make available detailed information about respondents, but collect only limited information about their parents (e.g., age, education, and occupation). ${ }^{2}$ To resolve this data problem, we use occupational characteristics from the Dictionary of Occupational Titles (DOT) to proxy for parents' skills. This proximization assumes the assignment model of interpersonal interaction developed by Borghans, ter Weel, and Weinberg (2008). Their model indicates that a worker's behavior is determined by job circumstances and the worker's personality, and that a worker with a comparative advantage in a certain behavior will be assigned to the job that demands that behavior more. They empirically test and confirm these model implications. ${ }^{3}$

\footnotetext{
${ }^{1}$ However, many researchers have examined the intergenerational correlations of earnings status and human capital. See Solon (1999) and Black and Devereux (2010) for a survey of this literature. Black, Devereux, and Salvanes $(2005,2009)$ estimate the intergenerational correlation in education and IQ scores, using Norway's large nationally representative data set. Currie and Moretti (2003) study the effect of maternal education on birth outcomes using U.S. Vital Statistics Natality data. Plug and Vijverberg (2003) use U.S. adoption data to separate out nature and nurture effects on education. The family link in labor supply is studied by Altonji and Dunn (1991), using the National Longitudinal Surveys.

${ }^{2}$ Studies based on homogeneous subsamples suffer from attenuation, which results in lower correlation estimates than those in studies based on large and representative population samples. Moreover, Duncan, Kalil, Mayer, Tepper, and Payne (2005) note that the problem with most psychological studies examining the intergenerational link in traits and behaviors is that virtually all focus on maternal characteristics, not paternal ones.

${ }^{3}$ The assumption that the workers hold occupations that match their traits and personalities also corresponds to this observation by Robert Hauser $(1998,5)$ : "Job-holding tells us about the technical and social skills that we bring to the labor market. . . . As market labor has become nearly universal among adult women as well as men, it is increasingly possible to characterize individuals in terms of their own current or
} 
The purpose of this paper is to test the hypothesis that parents' social skills have an effect on their children's sociability, even after controlling for a variety of background characteristics. We take advantage of the fact that NLSY79 respondents (the children of the parents in question) were asked about their own degree of sociability at age 6 and in early adulthood, and the number of clubs in which they participated during high school. Their parents' social skills are latent and not directly described, but we observe people skills that are required on the parents' jobs (as extracted from the DOT). We use the people skills from the DOT as a proxy for individuals' sociability, because Borghans, ter Weel, and Weinberg (2006), using data from the NLSY79 and the British Cohort Study (BCS), find that youthful sociability is strongly related to the importance of people tasks in individuals' subsequent occupations. After controlling for the parents' education and income and for the children's education and cognitive skills, we find that many of the parents' DOT people-skill variables have positive effects on their children's sociability. Yet many of the parents' DOT people-skill variables are also positively related with their DOT cognitive skills and negatively related with their DOT motor skills and physical strength. Thus, we investigate whether the intergenerational effects remain when we control for the correlation between parents' people skills and their other skill dimensions. Specifically, we take two approaches to extracting parents' social skills from DOT skills to obtain a measure of latent sociability.

First, following studies that group the skill characteristics from the DOT with factor analysis (e.g., Ingram and Neumann, 2006; Bacolod and Blum, 2010), we perform factor analyses on the parents' DOT characteristics to extract their latent people skills. Second, we apply the method used by psychometricians to estimate general intelligence (abbreviated g). ${ }^{4}$ Specifically, each of the parents' DOT people skills is projected separately onto their DOT non-people skills (e.g., cognitive skills, motor skills, and physical strength), because the people skills are correlated with the non-people skills. Projection errors are then used as a measure of social skills that do not overlap with the non-people skills. These projection errors are grouped by principal component analysis; the first principal component, which explains the largest fraction of common variation among these errors, is referred to as the parents' latent people skills.

Both approaches yield a positive and significant link between fathers' people skills and past jobs."

${ }^{4}$ Spearman (1904) proposed the existence of general intelligence, termed $g$, which is a single general factor that governs the level of intelligence of an individual. See Cawley, Conneely, Heckman, and Vytlacil (1997) for the development of the literature on this subject. 
sons' sociability in early adulthood but an insignificant link with their sons' sociability at age 6. Specifically, a one-standard-deviation increase in fathers' sociability increases the sons' early-adulthood sociability by .085 standard deviations. The father-daughter, mother-son, and mother-daughter links are much weaker for children's sociability, both at age 6 and in early adulthood. The weak results for mothers may be caused by the fact that in the 1970s, mothers' occupations may not have fully reflected their underlying abilities and personality traits.

To focus on the mother-child relationship, we use the NLSY79 sample of female respondents and their children. In this sample, we have information on the degree of sociability for mothers (female respondents) at age 6 and as adults, and for their sons and daughters between the ages of 2 and 6 . We also have information on people skills extracted from the DOT of NLSY79 female respondents whose employment rates are much higher than those of the mothers of NLSY79 respondents. A positive relation is found between mothers and daughters, but the relation between mothers and sons is weaker. We conclude that parents' social skills have a positive effect on their children's sociability along gender lines. Fathers' people skills affect their sons' sociability in early adulthood. Mothers' sociability affects their daughters' sociability in early childhood. These results suggest that sons' social skills are nurtured by their fathers during adolescence or early adulthood and are thus probably not genetically transmitted from fathers to sons. Since mothers' social skills are transmitted when daughters are young, however, we cannot rule out the possibility of genetic transmission.

An emerging body of literature has established the importance of noncognitive skills to individuals' success in social and economic life (see Bowles, Gintis, and Osborne (2001), Heckman, Stixrud, and Urzua (2006), among many others). Noncognitive skills are multidimensional and include many aspects of personality traits, such as sociability, self-esteem, motivation, persistence, time preference, and risk aversion. Among these various noncognitive skills, we focus in this paper on sociability. ${ }^{5}$ Using the U.K. National Child Development Study, Machin et al. (2001) find that being particularly sociable positively affects earnings by 2 percent based on a 5-scale measure of sociability. For the NLSY79 respondents, we find positive and significant labor market returns to sociability, as shown in Table 7. For example,

\footnotetext{
${ }^{5}$ The most widely accepted taxonomy of personality traits is called the Big Five or the five-factor model (FFM). The Big Five factors are openness to experience, conscientiousness, extroversion, agreeableness, and neuroticism. Sociability is included under extroversion, which is characterized by facets such as gregariousness, assertiveness, activity, and outgoingness. See McCrae and John (1992) and Borghans, Duckworth, Heckman, and ter Weel (2007) for details.
} 
a one-standard-deviation increase in early-adulthood sociability raises men's wages by 1.64 percent. Because sociability is found to have a positive effect on wages, the intergenerational link in sociability identified in our paper raises wages in the next generation. In fact, a onestandard-deviation increase in fathers' sociability would increase sons' wages by .139 percent. (This number is derived by multiplying the intergenerational effect on sociability (.085) by the labor market returns to sociability (1.64).) For comparison, a one-standard-deviation increase in fathers' education would increase sons' wages by .874 percent (derived by the intergenerational effect on education and the labor market returns to education). The dollar value to the sons of a given increase in their fathers' sociability is one-sixth the value to the sons of the same standard-deviation increase in their fathers' education, reflecting the smaller labor market returns to sociability than to education. In summary, fathers' sociability has a positive and significant effect on sons' sociability and a nonnegligible effect on sons' wages; however, the latter is nevertheless small in comparison to the effect of fathers' education on wages. ${ }^{6}$

The paper proceeds as follows. Section 2 describes the data used in the analysis and includes descriptive statistics for the NLSY79 sample. Estimation results are documented in Section 3. The paper concludes in Section 4.

\section{Data and Descriptive Statistics}

\subsection{Data}

\subsubsection{Dictionary of Occupational Titles (DOT)}

We draw information about occupational characteristics from the Fourth Edition (1977) of the U.S. Department of Labor's Dictionary of Occupational Titles (DOT). Using guidelines supplied by the Handbook for Analyzing Jobs, Department of Labor examiners evaluated more than 12,000 occupations along objective and subjective dimensions, including work functions, general educational development, worker aptitudes, temperaments, interests, physical strength, and environmental conditions. ${ }^{7}$ The DOT characteristics represent not only

\footnotetext{
${ }^{6}$ Okumura and Usui (2009) extend the models of transmission of human capital from parents to children which were developed by Becker and Tomes (1976) and Laband and Lentz (1993) to the case where human capital is multidimensional, consisting of cognitive, people, and motor skills, as well as physical strength. They then study how the difference in parents' skill holdings influences the difference in children's wages through intergenerational skill transfer.

${ }^{7}$ The DOT has been used for job-matching applications, occupational and career guidance, employment counseling, and labor-market information services.
} 
skills related to education (e.g., reasoning ability, mathematical ability, and language development), but also skills related to individuals' personality traits (e.g., adaptability in dealing with people, and preference for activities involving business contacts with people). The data in the fourth edition of the DOT (1977) were collected between 1966 and 1976; the DOT skill measures thus describe occupations in the 1970s which overlap with the parents' occupations in the years of our study. Our DOT data construction follows Autor, Levy, and Murnane (2003). ${ }^{8}$ All DOT variables are standardized to have a mean of zero and a standard deviation of one in the 1971 CPS distribution.

The textual definitions of DOT variables are utilized to identify a given DOT people-skill category. ${ }^{9}$ The identified DOT people-skill variables are:

(1) Talking and/or hearing.

(2) Adaptability to dealing with people beyond giving and receiving instructions.

(3) Adaptability to situations involving interpretations of feelings, ideas, or facts from personal viewpoints.

(4) Adaptability to influencing people in their opinions, attitudes, or judgments about ideas or things.

(5) A preference for communication of data versus a preference for dealing with things.

(6) A preference for working for the presumed good of people versus a preference for activities that are carried out in relation to processes, machines, and techniques.

(7) A preference for activities involving business contacts with people versus a preference for activities of a scientific and technical nature.

(8) A complexity of function in relation to people. ${ }^{10}$

${ }^{8}$ As DOT job codes are more detailed than census occupational codes, the DOT job codes are mapped to the 1970 census occupational codes at the three-digit level. Following Autor, Levy, and Murnane (2003), we use the April 1971 Current Population Survey (CPS) issued by the National Academy of Sciences (1981), in which experts assign individual DOT job codes to each of the 60,441 workers in the sample. The DOT measures are rescaled so that higher values denote higher requirements and are transformed into percentile values corresponding to their rank in the 1971 distribution of skill input. Then they are standardized to mean zero and standard deviation of one. The 1971 CPS sampling weights are used to calculate the means of each DOT characteristic by occupation and gender. In cases where an occupation cell contains exclusively men or women, the cell mean is assigned to both genders. To verify that our results are robust to plausible alternative specifications of the DOT variables, we employ raw DOT scores in a separate analysis. Results are qualitatively identical.

${ }^{9}$ Autor, Levy, and Murnane (2003), Bacolod, Blum, and Strange (2009), Bacolod and Blum (2010), and Yamaguchi (2010) also utilize the textual definitions to classify DOT variables in order to analyze changes in skill requirements and skill returns in the U.S. Ingram and Neumann (2006) use factor analysis on the revised fourth-edition DOT data to reduce the data to a more parsimonious set of dimensions. We also implement a factor analysis to corroborate our choice of skill categories. Most of our skill categorizations are consistent with the grouping from the factor analysis. See Appendix Table 5 for the factor loadings for each DOT variable.

${ }^{10}$ There is some variation in the choice of DOT people-skill variables in previous studies. Borghans, ter 
The remaining DOT non-people-skill variables are broadly classified into three categories: cognitive skills, motor skills, and physical strength. These DOT skill variables are described in detail in Appendix Table 1.

\subsubsection{National Longitudinal Survey of Youth 1979 (NLSY79)}

This survey is sponsored by the Bureau of Labor Statistics of the U.S. Department of Labor, and features a panel data set begun in 1979 to gather information on individuals between the ages of 14 and 22. The survey covers a large range of topics, including respondents' education, aptitudes, cognitive test scores, and labor-force experiences. We restrict the sample to whites because in this study we are using occupational characteristics to proxy for parental skills, and there is good reason to believe that minorities in the 1970s may have faced barriers and discrimination preventing them from working in occupations fully reflective of their abilities and personal traits.

In selected survey years, the NLSY79 collected information from respondents on their sociability. We utilize the questionnaires in the 1985 wave of the NLSY79, which asked respondents between the ages of 20 and 28 directly about their degree of sociability. Specifically, the NLSY79 asked:

(i) How sociable they were in early adulthood. ("Thinking about yourself as an adult, would you describe yourself as: (1) extremely shy, (2) somewhat shy, (3) somewhat outgoing, or (4) extremely outgoing?"), and

(ii) How sociable they were at age 6. ("Thinking about when you were 6 years old, would you describe yourself as: (1) extremely shy, (2) somewhat shy, (3) somewhat outgoing, or (4) extremely outgoing?").

We also use the survey in the 1984 wave, which asked:

(iii) In how many clubs did they participate during high school. ${ }^{11}$

Because the sociability measure is unavailable for NLSY79 parents, we match the parents'

Weel, and Weinberg (2006) construct a people-task measure by summing variables (2), (3), (4), (6), and (7). Bacolod, Blum, and Strange (2009), Bacolod and Blum (2010), and Yamaguchi (2010) take variables (2), (4), and (8), and add another variable-temperaments accepting responsibility for planning activity-in order to construct a people-skill index using a factor analysis. We also employ the variable selection from these studies and obtain similar results.

${ }^{11}$ Respondents were shown a handcard with high school clubs and asked how many of them they participated in during high school. The clubs were: (1) community youth organizations such as Scouts, the Y, and Junior Achievement; (2) school-sponsored hobby or subject-matter clubs such as photography or history; (3) student council or student government; (4) the staff of yearbooks, school newspapers, magazines, manuals; (5) athletics, including cheerleading and pep clubs; (6) performing arts, including band, drama, and orchestra; (7) a national honor society or a scholastic achievement club; and (8) other (specify). 
occupations at the three-digit level when the respondents were age 14 to DOT skills and let DOT people skills stand for the parents' people skills. ${ }^{12}$ Borghans, ter Weel, and Weinberg (2006) find that the three measures of NLSY79 respondents' sociability shown above as $(i)$, (ii), and (iii) have a large positive effect on their people-task measure summing the DOT people skills (2), (3), (4), (6), and (7) as listed in Section 2.1.1. We confirm their findings in Appendix Table 2 by using our measures of DOT people skills. In that table, all the DOT people skills, except DOT people skill (3) ("interpret feelings"), are positively and significantly related to the respondents' self-reported sociability measures shown above as $(i)$, (ii), and (iii).

To aid in our comparison, we examine the sociability link between NLSY79 female respondents and their children. Beginning in 1986, children of NLSY79 female respondents were given assessments biennially in the NLSY79 Children and Young Adult Survey. From this survey we take two kinds of information about children's sociability: (1) attitude tests on sociability as assessed by mothers who were surveyed when their children were between the ages of 2 and 6 , and (2) whether the children reported belonging to a club in or out of school between the ages of 10 and 14 . As attitude tests on sociability increase in number with children's age, the scores are age-standardized to have a mean of zero and a standard deviation of one. For mothers of NLSY79 children, we use sociability measures obtained in the 1984 and 1985 waves, as well as their DOT people skills.

As will be shown in Section 2.2, individuals' sociability is positively associated with their cognitive skills. Therefore, parents' and children's education and children's cognitive test score - specifically, their scores on the Armed Forces Qualification Test (AFQT) - are used as a control to estimate the effect of the intergenerational link in sociability. The AFQT is a battery of tests used by the military for enlistment, screening, and job assignments. These tests measure basic numeracy and literacy skills and were administered to almost the entire NLSY79 sample. Test scores have been age-standardized, so that they have a mean of zero and a standard deviation of one.

\subsection{Descriptive Statistics}

We begin by providing basic facts regarding the relation between children's sociability and parents' DOT skill variables. These indicate that children's sociability is positively related

\footnotetext{
${ }^{12}$ If the information on parents' occupation when the respondent was 14 is unavailable, we substitute with their occupation in 1978, when the respondent was between the ages of 13 and 20 .
} 
with their own education and their parents' education, with their cognitive skills, and with their people skills, and is negatively related with their parents' motor skills and physical strength.

Table 1 presents the means and standard deviations of the children's variables. Since the children were between the ages of 20 and 28 in 1985, some of them were enrolled in college. We divide the sample into those with high-school or less-than-high-school education and those with greater-than-high-school education. Children with greater education are more likely to report that they are sociable, both as adults and when they were age 6 . For those with high-school or less-than-high-school education, the average number of clubs participated in during high school is .73 for sons and 1.03 for daughters. For children with greater-than-highschool education, the average for sons is 2.04 and for daughters, 2.41. It appears that high sociability is associated with a higher educational level and greater financial resources. For both education groups, children are more likely to report that they are more sociable in their twenties than they were at age 6 .

Table 2 displays the means and standard deviations of parents' variables. For both fathers and mothers, education is positively associated with DOT cognitive-skill and DOT peopleskill variables, but inversely associated with DOT motor-skill and DOT physical-strength variables. Among fathers, 95.8 percent worked for pay, while only 52.4 percent of mothers did so. A strong positive relation can be seen between a mother's education and her participation in the labor force, although her decision to work could also have been influenced by her spouse's earnings or his health. Therefore, the analysis in Section 3 that uses the mothers' DOT skills to proxy her people skills faces the problem of sample selection bias, but the analysis in that section using the direct measures of sociability between mother and child is free of selection bias.

In Appendix Table 3 we show the correlations between children's and parents' skills. Children's education, AFQT score, and the number of clubs participated in during high school are positively correlated with their parents' DOT cognitive and people skills, and negatively correlated with their parents' DOT motor skills and physical strength. Children's sociability at age 6 and in early adulthood is similarly correlated with the parents' variables but to a lesser degree. Parents' DOT cognitive skills are more correlated with their children's sociability at age 6 than with their children's sociability as young adults. These finding suggest that both the cognitive and the people skills of parents may play a role in shaping children's sociability, and the contribution of parents' cognitive skills may be greater when children are young. 


\section{Effect of Parents' People Skills on Children's Socia- bility}

In this section, we examine the effect of parents' people skills on children's sociability. NLSY79 respondents were questioned as to their own sociability, but not that of their parents; therefore, DOT people skills are used to proxy for parents' sociability. In Section 3.1, we start by estimating the effect of the parents' DOT people-skill variables on their children's sociability, controlling for various background characteristics. However, since the DOT people-skill variables are correlated with DOT non-people-skill variables as noted in Section 2.2, we need to address the possibility that the link between parents' DOT people skills and children's sociability may arise from the link between parents' DOT non-people skills (such as cognitive skills) and children's sociability. To isolate parents' people skills from their non-people skills, we take two different approaches in Sections 3.2 and 3.3, respectively.

\subsection{Raw DOT People Skills as Sociability Measures}

We estimate the effect of the parents' DOT people-skill variable on their children's sociability (i.e., sociability at age 6 and in early adulthood, and the number of clubs participated in during high school). In addition to the raw DOT people-skill variable as a regressor, we also use: $(i)$ the average of all the DOT people skills in Section 2.1.1 and (ii) the people-task measure of Borghans, ter Weel, and Weinberg (2006) that sums the DOT people skills (2), (3), (4), (6), and (7) in Section 2.1.1. The results presented in Appendix Table 4 are estimated by ordered probit, and are controlled for children's education, quadratic of children's AFQT score, children's age and parents' age, parents' education, dummies for not living with both parents and for place of residence (region and urban area) when the children were age 14, and three-year averages of family size and household income in 1978, 1979, and 1980.

The fathers' DOT people-skill variables (except "interpret feelings" and "influencing people") have positive and significant effects on children's sociability at age 6 and in early adulthood, but none of these variables have a positive and significant effect on the number of clubs their children participated in (Appendix Table 4, Panel A, Columns 1, 2, and 3). The mothers' DOT people-skill variables also have positive and significant effects on children's sociability in early adulthood, but fewer variables are significant for their children's sociability at age 6 , and many variables are insignificant for the number of clubs their children participated in (Appendix Table 4, Panel B, Columns 1, 2, and 3). After controlling for parents' education 
and income and children's cognitive skills, parents' DOT people-skill variables still positively affect children's sociability at age 6 and in early adulthood, but no longer affect children's club participation. In the following analysis, we focus on the relation between parents' people skills and their children's sociability at age 6 and as an adult.

When we match fathers and sons, many of the fathers' DOT people-skill variables have positive and significant effects on their sons' sociability in early adulthood, but insignificant effects on it at age 6 . In contrast, for father-daughter pairs, many effects are positive and significant for the daughters' sociability at age 6, but such effects are fewer for the daughters' sociability in early adulthood (Appendix Table 4, Panel A, Columns 4, 5, 7, and 8). Between mother-son and mother-daughter pairs, the differences in estimates on sociability are small and only a scattering of variables are significant (Appendix Table 4, Panel B, Columns 4, 5, 7, and 8). Overall, the results in Appendix Table 4 provide weaker evidence for mothers than for fathers with respect to the intergenerational link in social skills.

Since the mothers' results in Appendix Table 4 may be biased because their occupations in the 1970s may not have fully reflected their personality traits, we estimate the relation in the degree of sociability between the NLSY79 female respondents and their children as seen in Table 3. The OLS estimates control for mothers' education, quadratic in mothers' AFQT score, mothers' age and children's age, mothers' marital status, place of residence (region and urban area), three-year averages of family size and household income in 1983, 1984, and 1985, and year dummies. ${ }^{13}$ Mothers' sociability (at age 6 and in early adulthood) is positively related to children's sociability between 2 and 6 years old. Specifically, the estimated coefficients for the effect of the mothers' sociability at age 6 on their children's sociability between 2 and 6 years old are .049 (.019) for daughters and .027 (.018) for sons, whereas the corresponding effects of mothers' sociability in early adulthood are .035 (.020) for daughters and .028 (.018) for sons. The effect of the mothers' sociability on their daughters' sociability is larger and more significant than on that of their sons. ${ }^{14}$

\footnotetext{
${ }^{13}$ We report robust standard errors clustered by mothers.

${ }^{14}$ Duncan, Kalil, Mayer, Tepper, and Payne (2005) estimate standardized regression coefficients for motherchild links in sociability (both at age 6) and participation in clubs for a sample that includes all racial groups. They cluster the answers on mothers' sociability at age 6 into two values: zero for shyness (answers 1 or 2), one for outgoing (answers 3 or 4). They find a greater mother-daughter link than a mother-son link for participation in clubs, but not for sociability at age 6 . Specifically, the estimate for sociability is 13 for both mother-daughter and mother-son pairs (standard errors are not reported in their article). When we restrict the age range of children to 6 as in Duncan et al., the estimate for sociability is .039 (.034) for the motherdaughter link and .004 (.030) for the mother-son link. Although the effect for daughters is greater than that for the sons, the difference is insignificant.
} 
As NLSY79 female respondents are active in the labor market and 84.4 percent of them work for pay, it is even more sensible to proxy their skills using the DOT rather than the scanty data for mothers in the NLSY79. Many of the NLSY79 female respondents' DOT people skills have positive and significant effects on their daughters' sociability, but the effects are small and insignificant for that of their sons. For example, in Table 3, the estimated coefficients for the effect of the mothers' score on "relation to people" on their children's sociability are .076 (.031) for daughters and .002 (.031) for sons; for the mothers' score on "dealing with people," the estimates are .048 (.028) for daughters and .027 (.028) for sons.

The overall results in Table 3 indicate a stronger sociability link between mothers and daughters than between mothers and sons, a pattern which is not seen in the mother-child results in Appendix Table 4. We obtain clearer results on the mother-child relation when we compare direct measures on sociability between mothers and children or when we proxy the skills with the DOT variables for the NLSY79 female respondents.

\subsection{Sociability Measures From Factor Analysis: Approach I}

Factor analysis methods have been developed to reduce the dimensions of original observations and extract the common, usually independent, components. In our study, we apply factor analysis to the DOT skill variables to reduce the dimensions of the data and to extract measures of social skills that approximate parents' latent sociability.

Previous studies using the DOT adopt two different methods to identify the people skills. The first method, used by Bacolod and Blum (2010), Bacolod, Blum, and Strange (2009), and Yamaguchi (2010), assumes that a subset of DOT variables measures a single skill. This method constructs a people-skill index which is derived from the first component of the principal component analysis on DOT people skills (for textual definitions, see Appendix Table 1). This method is also used to construct a cognitive-skill index, a motor-skill index, and a physical-strength index. The second method, used by Ingram and Neumann (2006), assumes that a DOT variable contains information about several underlying skills that are orthogonally distributed. Thus, this method employs a factor analysis on all DOT skills, and extracts latent factors to represent the underlying skills. These factors are then labeled, on the basis of the items loading on them, as people skills, cognitive skills, motor skills, and physical strength. In this paper, we employ both of these methods to obtain parents' latent people skills, and to estimate the relation between parents' latent people skills and their children's sociability. 
In the first method, we construct a latent skill index for each of the four skill groups: people skills, cognitive skills, motor skills, and physical strength. Specifically, taking the corresponding occupational characteristics from the sample of NLSY79 parents (separately for fathers and mothers), we use a principal component analysis to reduce each skill dimension to one. By ordered probit, we then regress children's sociability on parents' skill indices while controlling for the same covariates as in Section 3.1. The results are presented in Table 4, Panel A. The estimated coefficient of the effect of fathers' people skills on sons' sociability in early adulthood is .100 (.046) (Table 4, Panel A, Column 3). This is the only positive and significant association. The effect of fathers' people skills on sons' sociability at age 6 is .052 (.044), which is smaller than the effect in early adulthood. In contrast to the results in Appendix Table 4, the positive effect of fathers' people skills on daughters' sociability at age 6 is no longer present.

In the second method, we use a factor analysis on all the DOT skill variables from the sample of NLSY79 fathers and mothers (separately for each group) in order to extract latent, orthogonal skill factors. The estimated factor loadings for each DOT variable are displayed in Appendix Table 5, Panel A for the sample of NLSY79 fathers, and Panel B for NLSY79 mothers. Each of the factors is identified and labeled on the basis of the DOT skill variables that loaded highly.

For NLSY79 fathers, the first, second, and third factors are identified as cognitive skills, motor skills, and physical strength, respectively. The fourth and fifth factors are labeled people skills. While both the fourth and fifth factors have high factor loadings on the DOT people-skill variables, the fourth factor has a relatively higher loading on "interpret feelings" and "influence people," and the fifth factor has a relatively higher loading on "dealing with people," "talking/hearing," and "business contact with people." ${ }^{15}$ From the sample of NLSY79 respondents, we find that the NLSY respondents' DOT people-skill variables, which are highly loaded on the fifth factor, are more strongly linked with those respondents' sociability measures than those highly loaded on the fourth factor (see Appendix Table 2). For this reason, we pay attention to the fifth factor's people skills in the estimation. ${ }^{16}$ For NLSY mothers, the first, second, and third factors are labeled cognitive, motor, and people skills,

\footnotetext{
${ }^{15}$ The first factor also has a high factor loading on the DOT people-skill variables, but a much higher factor loading on the DOT cognitive skill variables; we therefore label the first factor as cognitive skills.

${ }^{16}$ The sixth factor has a somewhat high factor loading on "eye-hand-foot coordination" and "color discrimination," so this factor is related to motor skills.
} 
respectively. The fourth through the seventh factors are labeled physical strength. ${ }^{17}$

We regress the children's sociability on six of the fathers' skill factors, and on eight of the mothers', and the results are reported in Table 4, Panel B. ${ }^{18}$ Just as we found with the first method, the second method also shows a positive and significant relation in sociability in father-son pairs, specifically, on the sons' sociability in early adulthood, for which the estimate is .059 (.022) (Table 4, Panel B, Column 3). The estimated effect on the sons' sociability at age 6 is .039 (.021), which is smaller but significant at the 10 percent level (Table 4, Panel B, Column 4). Consistent with the results from the sample of NLSY79 female respondents and their children in Table 3 of Section 3.1, a positive but weak association in sociability between mothers and daughters is found. Specifically, the effect of mothers' people skills on daughters' sociability at age 6 is .043 (.024), which is significant at the 10 percent level (Table 4, Panel B, Column 6). The effect of mothers' people skills on daughters' sociability in early adulthood, however, is only .025 (.026), and their effect on their sons' sociability at age 6 and as an adult are also both small and insignificant.

We also find that fathers' education has a significant positive effect on their sons' sociability at age 6. Fathers' education appears to play an important role in shaping the sons' sociability when the sons are young, while fathers' people skills help shape the sons' sociability as adults. In contrast, mothers' cognitive skills have a significant positive affect on sons' sociability at both stages and on daughters' sociability only as adults (Table 4, Panel B).

One weakness of the factor analysis employed in this section is that the estimated factors do not have an immediate economic interpretation; we cannot tell whether our people-skill factors capture the true set of social skills. Therefore, in the next section, we construct an alternative measure of social skills that are related to the DOT people-skill variables, but are orthogonal to the other DOT non-people-skill variables.

\subsection{Sociability Measures From Projection: Approach II}

Cawley, Conneely, Heckman, and Vytlacil (1997) construct measures of general intelligence by estimating principal components from the matrices of correlations of ten Armed Services Vo-

\footnotetext{
${ }^{17}$ Although these factors have relatively high loadings on DOT physical-strength variables, the fourth factor also has high loading on "spatial perception" and "make judgments"; the fifth factor has high loading on "perform variety of duties"; the sixth factor on "under stress," and the seventh factor on "color discrimination." The eighth factor has a high loading only for "interpret feeling."

${ }^{18}$ In Table 4, Panel B, the estimated coefficients on the effects of the fathers' sixth factor and the mothers' fifth to eighth factors on their children's sociability measures are not reported, as these estimates are all small and insignificant.
} 
cational Aptitude Battery test scores. Each of these ASVAB scores is "adjusted" by regressing it on the appropriate demographic characteristics of respondents; principal components are subsequently estimated from these residuals. Cawley et al. take this projection approach because it is well known that test-takers with certain demographic characteristics score higher on ability tests. We apply their approach to our analysis, because our eight DOT people-skill variables are related to the DOT non-people-skill variables, as described in Section 2.2.

The residual of the linear projection of the DOT people-skill variable on the DOT nonpeople-skill variables is used as a measure of "adjusted" sociability for parents. With this procedure, all overlaps of people skills with non-people skills are attributed to the non-people skills. Specifically, we residualize each of the eight DOT people-skill variables for parents in Section 2.1.1 on their non-people-skill variables, and the residuals are standardized to have mean zero and variance one. We take the principal components of the correlation matrix of these standardized residuals. The parents' people-skill component is the first principal component, defined by the eigenvector associated with the largest eigenvalue of the correlation matrix of the standardized residuals. ${ }^{19}$ The results reported in Table 5, Panel B, estimate the effect of the parents' people-skill component on their children's sociability, while controlling for both the same covariates as before, and the DOT non-people skill variables used to adjust the people skills. As a comparison, Table 5, Panel A reports the effect of the parents' peopleskill component on their children's sociability when the parents' people-skill component is constructed by taking the first principal component of the correlation matrix of the raw DOT people skills (i.e., the unadjusted people skills, derived by not residualizing each of the parents' people skills on the non-people skills).

When the parents' people-skill component is taken from the first principal component of the raw DOT people skills, the parents' people-skill component has a positive and significant effect on children's sociability for all parent-child pairs except for mother-daughter pairs (Table 5, Panel A). However, if the parents' people-skill component is taken from the first principal component of the residualized DOT people skills, the large effect remains only for father-son pairs. Specifically, the fathers' adjusted people-skill component has a positive and significant effect on their sons' sociability in early adulthood, with an estimate of .085 (.024) (Table 5, Panel B, Column 3), but its effect on their sons' sociability at age 6 is only .027 (.022), which is small and insignificant (Table 5, Panel B, Column 4). Fathers' education has significant

\footnotetext{
${ }^{19}$ The first principal component explains 32.2 percent of the variance in the matrix of correlations for fathers, and 46.5 percent for mothers.
} 
positive effects on sons' and daughters' sociability at age 6. The effect of mothers' adjusted people-skill component on children's sociability is small and insignificant. The results in Table 5, Panel B are similar to the ones obtained using Approach I (Table 4, Panels A and B): there is a positive relation between fathers' people skills and sons' sociability in early adulthood, but a much weaker relation with the other parent-child pairs.

The factor analysis method used in Approach I (Table 4, Panel B) extracts latent skill factors from the DOT skills, which are orthogonal to each other. The factor that has a high loading on the DOT people skills is considered to measure parents' latent people skills. But since the extraction is arbitrary, obtaining an economic interpretation of the factor is not a straightforward process. In contrast, the adjusted people-skill component constructed in Approach II (Table 5, Panel B) does not overlap with the other DOT skills; this approach therefore provides a "stricter" definition of latent people skills. ${ }^{20}$ The appendix explains the identification and biases that arise in using Approach I, Approach II, and the method using parents' unadjusted people skills. For father-son pairs and, in particular, sons' sociability in early adulthood, the estimates are positive and significantly large, and are about the same between the approaches that use unadjusted and adjusted people skills of the parents. The appendix shows that the effect of the fathers' latent people skills on their sons' sociability falls within the range of these estimated values. Therefore, the fathers' latent people skills have a positive effect on shaping their sons' sociability. On the other hand, for parent-child pairs other than father-son, the estimates from the adjusted people skills are much smaller than those from the unadjusted people skills. As shown in the appendix, this result implies that parents' latent people skills have a relatively small effect on children's sociability, in contrast to the large effect of the parents' latent cognitive skills.

\subsection{Robustness Checks}

We next conduct a number of robustness checks to verify our findings. We focus on the fatherson sample that uses the sociability measure from projection (Approach II), and present our results in Table 6.

\footnotetext{
${ }^{20}$ The fathers' "verbal" skill (the DOT cognitive-skill variable) has a positive effect of .210 (.111) on sons' sociability in early adulthood (result not reported in Table 5, Panel B). "Verbal" skill is likely to be related to both cognitive and people skills, since according to the DOT variable description in Appendix Table 1, it is the ability to understand the meaning of words and use them effectively; to comprehend language; to understand relationships between words; and to understand meanings of whole sentences and paragraphs. Therefore, both adjusted people skills (which do not overlap with "verbal") and "verbal" skill have positive effects on the sons' sociability.
} 
First to be addressed is the issue of birth order. Social skills of first-borns may be shaped through the influence of parents; however, those of later-borns may be affected by both parents and older siblings. As a result, while the effect of fathers' people skills on first-born sons' sociability reflects the intergenerational transfer of sociability, the sociability of later-born sons may be contaminated by sibling influence. We reestimate the effect of fathers' people skills on first-born sons' sociability as adults, which is .104 (.044); however, it is .070 (.030) for the later-born sons (Table 6, Columns 1 and 2). The estimates are positive for both; that for the first-born is larger, yet is not significantly different from that of the later-born.

A second concern is the validity of our assumption that fathers hold jobs based on their skill sets, since we have inferred their skills from the occupations in which they are employed. We compare fathers' job characteristics at different points of time, and examine whether fathers switch between occupations that require significantly different skill sets. The NLSY79 enables us to obtain information on fathers' occupations at different points of time between 1971 and 1979, because the NLSY79 sampled siblings in the target age group. Therefore, if the respondents had siblings of different ages, we know the fathers' occupation when the respondents were age 14 and when the siblings were age 14 . Of fathers, 52 percent were employed in the same occupation for multiple years, and the variations in the values of DOT skills were small over the years. Specifically, the within variation, which is the differences within fathers' DOT skills over time, is nearly one-fifth that of the between variation, which is the differences in the time averages of the DOT skills between fathers. ${ }^{21}$

A third concern is why fathers' people skills do not affect sons' sociability at age 6 . The results in Sections 3.2 and 3.3 indicate that fathers' people skills affect sons' sociability in early adulthood but not at age 6, suggesting further that fathers' people skills nurture sons during adolescence or early adulthood and are thus probably not genetically transmitted. However, the insignificant result for sons' sociability at age 6 may arise because the fathers' people skills were extracted from their occupations when their sons were age 14 and may not reflect their people skills when their sons were age 6 . To address this concern, we proxy the fathers' occupation when the respondents were at age 6 by the occupation when the oldest siblings were at age 14 . When we replace the fathers' people-skill component with that of the oldest siblings, the estimated effects of the fathers' people-skill component on their sons' sociability in early adulthood is .112 (.033), and on their sons' sociability at age 6 is .008

\footnotetext{
${ }^{21}$ For example, the within variation of the fathers' "verbal" is .115, and the between variation is .691. The within variation of "relation to people" is .134, and the between variation .592 .
} 
(.031). (Using the same sample, the estimated effects of respondent-reported fathers' people skills are .105 (.033) and .022 (.032), respectively (Table 6, Column 3).) Even though we use fathers' people skills when the older siblings are 14 years old (the respondents' average age is 12.5), fathers' people skills continue to have only a small and insignificant effect on sons' sociability at age 6. Fathers' people skills extracted from the DOT when sons are age 14 are sensible proxies for fathers' people skills when their sons are age 6. Therefore, using fathers' occupational information when their sons are eight years older will not be the only reason for the small and insignificant link between fathers' people skills and sons' sociability at age 6 .

A fourth concern is that occupational misclassification may bias our estimates because, if misclassification errors are uncorrelated with the equation error, the estimated effect of fathers' people skills on their sons' sociability will be attenuated. To address this potential problem, we use the fathers' people-skill component, which is based on sibling reports, as an instrument in the ordered probit model to estimate the effect of the fathers' people-skill component on sons' sociability. The estimated effect of the fathers' people skills on the sons' sociability in early adulthood by an IV ordered probit is .132 (.070), while the ordered probit estimate with the same sample is .105 (.033) (Table 6, Columns 3 and 4). In contrast, the IV ordered probit estimate on sons' sociability at age 6 is -.003 (.067), while the ordered probit estimate with the same sample is .022 (.032). The IV ordered probit estimates on sons' sociability are qualitatively consistent with the ordered probit estimates, but the former are noisier. We can thus conclude that fathers' people skills raise sons' sociability in early adulthood, but the rise in sons' sociability at age 6 is small and insignificant.

A fifth concern is the difference in the intergenerational effects according to the father's education level. The estimates for the effect of the fathers' people skills on the sons' sociability in early adulthood are .082 (.031) for fathers with high-school or less-than-high-school education and .118 (.056) for those with more-than-high-school education (Table 6, Columns 5 and 6 ). Both estimates are significant at the 10 percent level across the sample. The estimate for the effect of the fathers' people skills on the sons' sociability at age 6 is small and insignificant for the sample with less-than-high-school education, but positive and significant for the sample of fathers with more-than-high-school education, the latter estimate being .131 (.053). We therefore conclude that for fathers with more-than-high-school education, sociability links from fathers to sons begin in childhood, whereas those links appear only in early adulthood for fathers with less-than-high-school education.

Lastly, to fit our sociability measures to the broader literature on noncognitive skills, 
we examine how our results are affected by including other aspects of noncognitive skills as regressors. Among the many other aspects of noncognitive skills that are related to labor outcomes, the NLSY79 administered the Rotter Locus of Control Scale during the 1979 interviews and the Rosenberg Self-Esteem Scale during the 1980 interviews. The Rotter scale measures the degree of control individuals feel they possess over their life, and the Rosenberg scale measures perceived self-esteem. These measures have been used by Goldsmith, Veum, and Darity (1997) to establish that psychological capital makes a significant contribution to wages. Both the Rotter scale and the Rosenberg Self-Esteem Scale are positively correlated with sociability at age 6 and as an adult. ${ }^{22}$ When the Rotter scale and the Rosenberg SelfEsteem Scale are included as regressors in our estimation, the effect of fathers' people skills on sons' sociability at early adulthood is .078 (.024) and that on sons' sociability at age 6 is .024 (.023). Both estimates are about the same as those obtained in Section 3.3 (see Table 5, Panel B, Columns 3 and 4). From these facts, we can conclude that the positive effect of fathers' people skills on sons' sociability is independent of these noncognitive skills.

\subsection{Relationship between Sociability and Wages}

To summarize our findings in Sections 3.1-3.4, we find a positive and significant intergenerational link between fathers' and sons' sociability. Specifically, we conclude that a onestandard-deviation increase in fathers' people skills increases sons' early-adulthood sociability by .085 standard deviations (Table 5, Panel B). To make a comparison with the intergenerational effect on education, a one-standard-deviation increase in fathers' education increases sons' education by .084 (.023) standard deviations in the 1990 wave of the NLSY79. ${ }^{23}$ The intergenerational effect on sociability is thus about the same as that for education.

To provide guidance about how to interpret the magnitudes of our estimates, we place a dollar value (to the sons) on an increase in the fathers' people skills. To do this, we first estimate the effect of sociability on wages for the sample of NLSY79 respondents. The results are displayed in Table 7. All self-reported sociability for men and women has a positive and significant effect on wages. In particular, the effect of early-adulthood sociability on wages is .0164 (.0066) for men and .0202 (.0064) for women. ${ }^{24}$ This result is also found in Machin et al. (2001) who report small but positive labor market returns to sociability for men; however,

\footnotetext{
${ }^{22}$ The correlation coefficient between Rotter scale and early-adulthood sociability is .083, and that between the Rosenberg Self-Esteem Scale and early-adulthood sociability is .157.

${ }^{23}$ The estimate controls for the same covariates as in Table 5, Panel B.

${ }^{24}$ Sociability at age 6 and in early adulthood is standardized to have mean zero and variance one.
} 
they do not find a positive effect for women.

Multiplying the wage effect of sociability and the intergenerational effect on sociability, we find that the monetary value (to the sons) on a one-standard-deviation increase in fathers' people skills is .139 percent $(=.085 \times .164$ percent $)$. On the other hand, the monetary value (to the sons) on a one-standard-deviation increase in fathers' education is .874 percent (as the labor market return to education is .1040 (.0086)). The monetary value of the intergenerational transfer of sociability is less than that of education, because the labor market return to sociability is smaller than the labor market return to education. In summary, when compared with the effect of fathers' education on wages, the effect of fathers' sociability on sons' wages is small but nonnegligible.

\section{Concluding Remarks}

This paper has examined whether parents' social skills affect their children's sociability, after parents' and children's cognitive skills and other background characteristics are controlled for. Since we often lack data on parents' sociability, we constructed measures of their sociability using the occupational characteristics from the Dictionary of Occupational Titles (DOT). For the NLSY79 fathers and their children, we found that the fathers' social skills have a positive effect on shaping their sons' sociability in early adulthood, while the fathers' cognitive skills shape their children's sociability at age 6. For the NLSY79 female respondents and their children, we found a stronger link in sociability between mothers and daughters than between mothers and sons. Therefore, parents' social skills have a positive effect on the sociability of their children, but only for those of the same gender.

While previous studies have found a positive association in cognitive skills between parents and children (e.g., Black, Devereux, and Salvanes (2005, 2009)), we find a positive intergenerational link in sociability. Given the presumably complex interactions and the timing needed to transfer cognitive and social skills from parents to children, future research could use a sophisticated multidimensional human capital model and data to further explore the interplay of these transmissions. 


\section{Appendix: Identification of the Effect of Parents' La- tent Sociability on Children's Sociability}

In this appendix, we explain how the estimates of the effect of the parents' latent peopleskill component on children's sociability are biased as a result of using $(i)$ the factor analysis method from Approach I (results in Table 4, Panel B), (ii) Approach II, where the parents' people-skill component is adjusted by their non-people skills (results in Table 5, Panel B), and (iii) the method where the parents' people-skill component is not adjusted by their nonpeople skills (results in Table 5, Panel A). We then provide conditions to identify this effect in the three frameworks $(i),(i i)$, and $(i i i)$. We also show that even without these conditions, this effect falls within the range of the estimates obtained by using (ii) and (iii).

We observe parents' people skill $\left(P_{i}\right)$, cognitive skill $\left(C_{i}\right)$, motor skill $\left(M_{i}\right)$, and physical strength $\left(P h_{i}\right)$. Each of these parents' observed skills is composed of its latent skill components: the latent people-skill component $\left(\varepsilon_{P, i}\right)$, the latent cognitive-skill component $\left(\varepsilon_{C, i}\right)$, the latent motor-skill component $\left(\varepsilon_{M, i}\right)$, and the latent physical-strength component $\left(\varepsilon_{P h, i}\right)$. In the matrix form, these are represented as follows: ${ }^{25}$

$$
\left[\begin{array}{c}
C_{i} \\
M_{i} \\
P h_{i} \\
P_{i}
\end{array}\right]=\left[\begin{array}{llll}
a_{11} & a_{12} & a_{13} & a_{14} \\
a_{21} & a_{22} & a_{23} & a_{24} \\
a_{31} & a_{32} & a_{33} & a_{34} \\
a_{41} & a_{42} & a_{43} & a_{44}
\end{array}\right]\left[\begin{array}{c}
\varepsilon_{C, i} \\
\varepsilon_{M, i} \\
\varepsilon_{P h, i} \\
\varepsilon_{P, i}
\end{array}\right]
$$

The latent skill components are assumed to be independent of each other, have zero means, and have unit variances.

We assume that children's sociability $\left(S O C_{i}\right)$ is composed of their latent sociability $\left(\xi_{i}\right)$, as well as their parents' latent skill components and control variables $\left(\mathbf{W}_{i}\right.$ vector), such that:

$$
S O C_{i}=a_{51} \varepsilon_{C, i}+a_{52} \varepsilon_{M, i}+a_{53} \varepsilon_{P h, i}+a_{54} \varepsilon_{P, i}+a_{55} \xi_{i}+\mathbf{W}_{i}^{\prime} \gamma
$$

where $\xi_{i}$ is assumed to be independent of parents' latent skill components $\left(\varepsilon_{C, i}, \varepsilon_{M, i}, \varepsilon_{P h, i}\right.$, and $\left.\varepsilon_{P, i}\right)$ and has a zero mean and a unit variance. $\mathbf{W}_{i}$ is independent of parents' and children's latent components.

By combining Equations $(A .1)$ and $(A .2)$ and suppressing $\mathbf{W}_{i}^{\prime} \gamma$ to simplify notation, we

\footnotetext{
${ }^{25}$ The parents' observed skills are vectors that are composed of their respective DOT skill variables. In this Appendix, to clarify the difference in identification among approaches, the observed skill vectors are simplified to the scalars $C, M, P h$, and $P$, as are the latent skill vectors $\varepsilon_{C}, \varepsilon_{M}, \varepsilon_{P h}$, and $\varepsilon_{P}$.
} 
have:

$$
\left[\begin{array}{c}
C_{i} \\
M_{i} \\
P h_{i} \\
P_{i} \\
S O C_{i}
\end{array}\right]=\left[\begin{array}{ccccc}
a_{11} & a_{12} & a_{13} & a_{14} & 0 \\
a_{21} & a_{22} & a_{23} & a_{24} & 0 \\
a_{31} & a_{32} & a_{33} & a_{34} & 0 \\
a_{41} & a_{42} & a_{43} & a_{44} & 0 \\
a_{51} & a_{52} & a_{53} & a_{54} & a_{55}
\end{array}\right]\left[\begin{array}{c}
\varepsilon_{C, i} \\
\varepsilon_{M, i} \\
\varepsilon_{P h, i} \\
\varepsilon_{P, i} \\
\xi_{i}
\end{array}\right] .
$$

Therefore, parents' latent skill components affect children's sociability but that children's latent sociability has no effect on parents' observed skills, that is, that there is no reverse causality. Our goal is to identify the effect of the parents' latent people-skill component on their children's sociability $\left(a_{54}\right) \cdot{ }^{26}$

(i) Approach I: The factor analysis method of Approach I (results in Table 4, Panel B) utilizes the simple-structure criterion to estimate the matrix in Equation (A.1), which represents the relation between parents' observed skills and their latent skill components. In particular, the factor loadings for $C, M, P h$, and $P$ are placed on the first, second, third, and fourth rows, respectively, of the matrix $(A .1)$, with the on-diagonal elements being the highest loadings among the factor loadings (row elements). Therefore, the matrix $(A .1)$ and the parents' latent skill components $\left[\varepsilon_{C}, \varepsilon_{M}, \varepsilon_{P h}, \varepsilon_{P}\right]^{\prime}$ are identified. Then, the children's observed sociability $\left(S O C_{i}\right)$ is regressed on the identified $\varepsilon_{C, i}, \varepsilon_{M, i}, \varepsilon_{P h, i}$, and $\varepsilon_{P, i}$. The coefficient on $\varepsilon_{P}$ gives the estimate on $a_{54}$. Because matrix identification is based on statistical normalization, it is not straightforward to interpret in economic terms the identified latent skill components $\left[\varepsilon_{C}, \varepsilon_{M}, \varepsilon_{P h}, \varepsilon_{P}\right]^{\prime}$.

(ii) Approach II: Approach II (results in Table 5, Panel B) estimates the effect of the parents' adjusted people-skill component on their children's sociability $\left(\beta_{A D J}\right)$. This estimate $\beta_{A D J}$ is biased from $a_{54} / a_{44}$ by the amount shown in

$$
\operatorname{plim} \beta_{A D J}-\frac{a_{54}}{a_{44}}=\left\{\mathbf{a}_{4}\left[I-A^{\prime}\left(A A^{\prime}\right)^{-1} A\right] \mathbf{a}_{4}^{\prime}\right\}^{-1} \mathbf{a}_{4}\left[I-A^{\prime}\left(A A^{\prime}\right)^{-1} A\right]\left(\mathbf{a}_{5}{ }^{\prime}-\mathbf{a}_{4}{ }^{\prime} \frac{a_{54}}{a_{44}}\right),
$$

where

$$
A=\left[\begin{array}{llll}
a_{11} & a_{12} & a_{13} & a_{14} \\
a_{21} & a_{22} & a_{23} & a_{24} \\
a_{31} & a_{32} & a_{33} & a_{34}
\end{array}\right], \mathbf{a}_{4}=\left[\begin{array}{llll}
a_{41} & a_{42} & a_{43} & a_{44}
\end{array}\right], \text { and } \mathbf{a}_{5}=\left[\begin{array}{llll}
a_{51} & a_{52} & a_{53} & a_{54}
\end{array}\right] .
$$

\footnotetext{
${ }^{26}$ In general, the whole system (A.3) is not identified, because the symmetric covariance matrix of $[C, M, P h, P, S O C]^{\prime}$ has only 15 distinct elements, but the number of parameters in the matrix is 21 . Six additional restrictions on the parameters are necessary to identify the whole system (A.3).
} 
( iii) The method using the parents' unadjusted people skills: The estimated effect of the parents' unadjusted people-skill component on their children's sociability $\left(\beta_{U N A D J}\right)$ (results in Table 5, Panel A) has the bias of

$$
\operatorname{plim} \beta_{U N A D J}-\frac{a_{54}}{a_{44}}=\left(\mathbf{a}_{4} \mathbf{a}_{4}^{\prime}\right)^{-1} \mathbf{a}_{4}\left(\mathbf{a}_{5}^{\prime}-\mathbf{a}_{4}^{\prime} \frac{a_{54}}{a_{44}}\right) .
$$

Therefore, $\beta_{A D J}$ and $\beta_{U N A D J}$ may be inconsistent, depending on the matrix structure of Equation (A.3). When the following three sets of restrictions (as shown in Cases (1)-(3)) are imposed on the matrix structure, however, we can obtain consistent estimates of $a_{54}$ from either estimate $\left(\beta_{A D J}\right.$ or $\left.\beta_{U N A D J}\right)$ - or from both $\left(\beta_{A D J}=\beta_{U N A D J}\right)$.

Case (1): $a_{14}=a_{24}=a_{34}=0$ and $a_{44}=1$.

This restriction implies that $\mathbf{a}_{4}\left[I-A^{\prime}\left(A A^{\prime}\right)^{-1} A\right]\left(\mathbf{a}_{5}{ }^{\prime}-\mathbf{a}_{4}{ }^{\prime} a_{54} / a_{44}\right)$ equals zero in Equation $(A .4) ; \beta_{A D J}$ is thereby a consistent estimate of $a_{54} \cdot{ }^{27}$ However, $\beta_{U N A D J}$ is not necessarily consistent. In Equation (A.3), this restriction asserts that the parents' latent people-skill component $\left(\varepsilon_{P, i}\right)$ is an underlying component of their observed people skill $\left(P_{i}\right)$, but is not an underlying component of their observed non-people skills $\left(C_{i}, M_{i}\right.$, and $\left.P h_{i}\right)$. In Equation $(A .2)$, the coefficient $a_{54}$ is derived by regressing children's observed sociability $\left(S O C_{i}\right)$ on the parents' adjusted people skill $\left(\varepsilon_{P, i}\right)$, while controlling for parents' observed non-people skills and the $\mathbf{W}$ variables. ${ }^{28}$

Case (2): $a_{41}=a_{42}=a_{43}=0$ and $a_{44}=1$.

This restriction implies that $\mathbf{a}_{4}\left(\mathbf{a}_{5}^{\prime}-\mathbf{a}_{4}^{\prime} a_{54} / a_{44}\right)$ equals zero in Equation $(A .5) ; \beta_{U N A D J}$ is thereby a consistent estimate of $a_{54}$. However, $\beta_{A D J}$ is not necessarily consistent. This restriction asserts that the parents' latent people-skill component is identical to their observed people skill. In Equation (A.2), the coefficient $a_{54}$ is derived by regressing the children's observed sociability $\left(S O C_{i}\right)$ on their parents' observed people skill $\left(P_{i}=\varepsilon_{P, i}\right)$ while the $\mathbf{W}$ variables are controlled and the term $a_{51} \varepsilon_{C, i}+a_{52} \varepsilon_{M, i}+a_{53} \varepsilon_{P h, i}+a_{55} \xi_{i}$ is an error term that is independent of $P_{i}$.

Case (3): $a_{51}=a_{41} a_{54}, a_{52}=a_{42} a_{54}, a_{53}=a_{43} a_{54}$, and $a_{44}=1$.

\footnotetext{
${ }^{27}$ Note that $a_{44}$ is set to unity for normalization. Note also that in Case (1), matrix $\left[I-A^{\prime}\left(A A^{\prime}\right)^{-1} A\right]$ has a unity for the $(4,4)$ element and zeroes for all the other elements.

${ }^{28}$ In Approach II, we first regress parents' observed people skill $\left(P_{i}\right)$ on their observed non-people skills (i.e., $C_{i}, M_{i}$, and $\left.P h_{i}\right)$ and obtain the residuals as the parents' adjusted people skill. The parents' adjusted people skill is independent of $C_{i}, M_{i}$, and $P h_{i}$, which consist only of $\varepsilon_{C, i}, \varepsilon_{M, i}$, and $\varepsilon_{P h, i}$. Therefore, the parents' adjusted people skill is $\varepsilon_{P, i}$, because it is independent of $\varepsilon_{C, i}, \varepsilon_{M, i}$, and $\varepsilon_{P h, i}$.
} 
This restriction implies that $\mathbf{a}_{5}^{\prime}-\mathbf{a}_{4}^{\prime} a_{54} / a_{44}$ equals zero in Equations $(A .4)$ and $(A .5)$; both $\beta_{A D J}$ and $\beta_{U N A D J}$ are thereby consistent estimates of $a_{54}$.

If all three sets of assumptions do not hold, then $\beta_{A D J}$ and $\beta_{U N A D J}$ are biased above or below the parameter $a_{54}$; however, $a_{54}$ can be bounded by $\beta_{A D J}$ and $\beta_{U N A D J}$ under some assumptions. Let us simplify Equation $(A .3)$ to the case where non-people skills comprise only cognitive skills:

$$
\left[\begin{array}{c}
C_{i} \\
P_{i} \\
S O C_{i}
\end{array}\right]=\left[\begin{array}{ccc}
a_{11} & a_{14} & 0 \\
a_{41} & a_{44} & 0 \\
a_{51} & a_{54} & a_{55}
\end{array}\right]\left[\begin{array}{c}
\varepsilon_{C, i} \\
\varepsilon_{P, i} \\
\xi_{i}
\end{array}\right] .
$$

Assume that parents' latent skill components have positive effects on their observed skills $\left(a_{11}\right.$, $a_{14}, a_{41}$, and $a_{44}$ are positive), and that their own effects are greater than their cross-effects $\left(a_{11} a_{44}-a_{14} a_{41}>0\right)$. Then the parameter $a_{54} / a_{44}$ is bounded upward (downward) by $\beta_{A D J}$, and bounded downward (upward) by $\beta_{U N A D J}$, if and only if $a_{54} / a_{44}$ is greater (smaller) than $a_{51} / a_{41}$; this implies that $\varepsilon_{P, i}$ may have a relatively large (small) effect on $S O C_{i}$, as compared to $\varepsilon_{C, i}$.

In Table 5, Panels A and B, for father-son pairs, the estimates on the sons' sociability in early adulthood are significantly large and about the same (.053 (.025) for the unadjusted people skills, and .085 (.024) for the adjusted people skills), implying that the effect of fathers' latent people-skill component on their sons' sociability $\left(a_{54} / a_{44}\right)$ is within the range of these values. On the other hand, for other parent-child pairs, the results indicate that $\beta_{A D J}$ is smaller than $\beta_{U N A D J}$, implying that $a_{54} / a_{44}$ is smaller than $a_{51} / a_{41}$, that is, parents' latent people-skill component has a relatively small effect on their children's sociability, which is in contrast to the larger effect of parents' latent cognitive-skill component.

\section{References}

[1] Altonji, Joseph G. and Thomas A. Dunn. 1991. Family Incomes and Labor Market Outcomes of Relatives. Research in Labor Economics, Vol. 12. JAI Press. 269-310.

[2] Autor, David H., Frank Levy, and Richard J. Murnane. 2003. The Skill Content of Recent Technological Change: An Empirical Exploration. Quarterly Journal of Economics, 118(4), 1279-333.

[3] Bacolod, Marigee, Bernardo S. Blum, and William C. Strange. 2009. Skills in the City. Journal of Urban Economics. 65(2), 136-53. 
[4] Bacolod, Marigee and Bernardo S. Blum. 2010. Two Sides of the Same Coin: U.S. "Residual Inequality" and the Gender Gap. Journal of Human Resources, 45(1), 197-242.

[5] Becker, Gary S. and Nigel Tomes. 1976. Child Endowments, and the Quantity and Quality of Children. Journal of Political Economy, 84(4), 143-62.

[6] Black, Sandra E. and Paul J. Devereux. 2010. Recent Developments in Intergenerational Mobility. NBER Working Paper 15889.

[7] Black, Sandra E., Paul J. Devereux, and Kjell G. Salvanes. 2005. Why the Apple Doesn't Fall Far: Understanding Intergenerational Transmission of Human Capital. American Economic Review, 95(1), 437-49.

[8] Black, Sandra E., Paul J. Devereux, and Kjell G. Salvanes. 2009. Like Father, Like Son? A Note on the Intergenerational Transmission of IQ Scores. Economics Letters, 105(1), 138-40.

[9] Borghans, Lex, Bas ter Weel, and Bruce A. Weinberg. 2006. People People: Social Capital and the Labor Market Outcomes of Underrepresented Groups. NBER Working Paper No. 11985.

[10] Borghans, Lex, Bas ter Weel, and Bruce A. Weinberg. 2008. Interpersonal Styles and Labor Market Outcomes. Journal of Human Resources, 43(4), 815-58.

[11] Borghans, Lex, Angela Lee Duckworth, James J. Heckman, and Bas ter Weel. 2008. The Economics and Psychology of Personality Traits. Journal of Human Resources, 43(4), 972-1059.

[12] Bowles, Samuel, Herbert Gintis, and Melissa Osborne. 2001. The Determinants of Earnings: A Behavioral Approach. Journal of Economic Literature, 39(4), 1137-76.

[13] Cawley, John, Karen Conneely, James Heckman, and Edward Vytlacil. 1997. Cognitive Ability, Wages and Meritocracy. In: Bernie Devlin, Stephen Fienberg, Daniel Resnick, and Kathryn Roeder, eds. Intelligence, Genes, and Success: Scientists Respond to the Bell Curve (New York, NY: Springer Verlag), 179-92.

[14] Currie, Janet and Enrico Moretti. 2003. Mother's Education and the Intergenerational Transmission of Human Capital: Evidence from College Openings. Quarterly Journal of Economics, 118(4), 1495-532. 
[15] Duncan, Greg, J., Ariel Kalil, Susan E. Mayer, Robin Tepper, and Monique R. Payne. 2005. The Apple Does Not Fall Far From the Tree. In Melissa Osborne, Samuel Bowles, and Herbert Gintis, eds. Unequal Chances: Family Background and Economic Success (New York: Russell Sage).

[16] Goldsmith, Arthur H., Jonathan R. Veum, and William Darity, Jr. 1997. The Impact of Psychological and Human Capital on Wages. Economic Inquiry, 35(4), 815-29.

[17] Hauser, Robert M. 1998. Intergenerational Economic Mobility in the United States: Measures, Differentials, and Trends. CDE Working Paper No. 98-12. University of WisconsinMadison.

[18] Heckman, James. J., Jora Stixrud, and Sergio Urzua. 2006. The Effects of Cognitive and Noncognitive Abilities on Labor Market Outcomes and Social Behavior. Journal of Labor Economics, 24(3), 411-82.

[19] Ingram, Beth F. and George R. Neumann. 2006. The Returns to Skill. Labour Economics, $13(1), 35-59$.

[20] Kuhn, Peter and Catherine J. Weinberger. 2005. Leadership Skills and Wages. Journal of Labor Economics, 23(3), 395-436.

[21] Laband, David N. and Bernard F. Lentz. 1983. Like Father, Like Son: Toward an Economic Theory of Occupational Following. Southern Economic Journal, 50(2), 474-93.

[22] Machin, Stephen, Steven McIntosh, Anna Vignoles, and Tarja Viitanen. 2001. Basic Skills, Soft Skills and Labour Market Outcomes: Secondary Analysis of the National Child Development Study. Research Report No. 250 (London: DfEE Research Centre).

[23] McCrae, Robert R., and Oliver P. John. 1992. An Introduction to the Five-Factor Model and Its Applications. Journal of Personality, 60, 175-215.

[24] National Academy of Science, Committee on Occupational Classification and Analysis. 1981. Fourth Edition Dictionary of DOT Scores for 1970 Census Categories. ICPSR Document No. 7845 (Ann Arbor, MI).

[25] Okumura, Tsunao and Emiko Usui. 2009. Intergenerational Transmission of Skills and Differences in Labor Market Outcomes for Blacks and Whites. Working Paper. Nagoya University, Japan. 
[26] Plug, Erik and Wim Vijverberg. 2003. Schooling, Family Background, and Adoption: Is it Nature or Is it Nurture? Journal of Political Economy, 111(3), 611-41.

[27] Solon, Gary. 1999. Intergenerational Mobility in the Labor Market. In Orley Ashenfelter and David Card eds. Handbook of Labor Economics. Vol. 3A. 1761-1800 (Amsterdam: North-Holland).

[28] Spearman, Charles, E. 1904. "General Intelligence" Objectively Determined and Measured. American Journal of Psychology, 15, 201-93.

[29] U.S. Department of Labor, Employment and Training Administration. 1977. Dictionary of Occupational Titles: Fourth Edition (Washington, DC).

[30] U.S. Department of Labor, Employment and Training Administration. 1991. Dictionary of Occupational Titles: Revised Fourth Edition (Washington, DC).

[31] Yamaguchi, Shintaro. 2010. Career Progression and Comparative Advantage. Labour Economics 17(4), 679-89. 
Table 1: Comparison of Means and Standard Deviations of Selected Variables of Children (NLSY Respondents)

Sample: Children (NLSY Respondents)

\begin{tabular}{|c|c|c|c|c|c|c|c|c|}
\hline \multirow[b]{3}{*}{ Variable } & \multicolumn{4}{|c|}{ Sons } & \multicolumn{4}{|c|}{ Daughters } \\
\hline & \multicolumn{2}{|c|}{$\begin{array}{c}\text { High School or } \\
\text { Less than High } \\
\text { School }\end{array}$} & \multicolumn{2}{|c|}{$\begin{array}{c}\text { More than High } \\
\text { School }\end{array}$} & \multicolumn{2}{|c|}{$\begin{array}{l}\text { High School or } \\
\text { Less than High } \\
\text { School }\end{array}$} & \multicolumn{2}{|c|}{$\begin{array}{c}\text { More than High } \\
\text { School }\end{array}$} \\
\hline & Mean & SD & Mean & SD & Mean & SD & Mean & SD \\
\hline Age & 23.52 & 2.295 & 23.92 & 2.326 & 23.62 & 2.290 & 23.77 & 2.295 \\
\hline Education & 11.34 & 1.191 & 14.94 & 1.568 & 11.43 & 1.183 & 14.81 & 1.379 \\
\hline AFQT & -0.212 & 0.884 & 0.855 & 0.660 & -0.232 & 0.823 & 0.720 & 0.664 \\
\hline School Enrollment & 0.025 & 0.156 & 0.357 & 0.479 & 0.026 & 0.160 & 0.335 & 0.472 \\
\hline \multicolumn{9}{|l|}{ Sociability at Age 6} \\
\hline Extremely shy & 0.140 & 0.347 & 0.098 & 0.297 & 0.205 & 0.404 & 0.134 & 0.341 \\
\hline Somewhat shy & 0.469 & 0.499 & 0.426 & 0.495 & 0.415 & 0.493 & 0.434 & 0.496 \\
\hline Somewhat outgoing & 0.276 & 0.447 & 0.346 & 0.476 & 0.248 & 0.432 & 0.270 & 0.444 \\
\hline Extremely outgoing & 0.114 & 0.318 & 0.131 & 0.337 & 0.132 & 0.339 & 0.163 & 0.369 \\
\hline \multicolumn{9}{|l|}{ Sociability at Early Adulthood } \\
\hline Extremely shy & 0.011 & 0.102 & 0.004 & 0.061 & 0.010 & 0.101 & 0.006 & 0.079 \\
\hline Somewhat shy & 0.266 & 0.442 & 0.250 & 0.433 & 0.252 & 0.434 & 0.209 & 0.407 \\
\hline Somewhat outgoing & 0.562 & 0.496 & 0.576 & 0.494 & 0.557 & 0.497 & 0.591 & 0.492 \\
\hline Extremely outgoing & 0.161 & 0.368 & 0.170 & 0.376 & 0.181 & 0.385 & 0.193 & 0.395 \\
\hline No. of High School Clubs Participated In & 0.733 & 0.943 & 2.043 & 1.531 & 1.026 & 1.268 & 2.412 & 1.696 \\
\hline NLSY Children: Sociability Score & & & & & -0.025 & 1.008 & 0.039 & 0.969 \\
\hline NLSY Children: Belong to Club & & & & & 0.629 & 0.484 & 0.824 & 0.381 \\
\hline Family Size & 4.007 & 1.617 & 3.858 & 1.668 & 3.868 & 1.545 & 3.821 & 1.535 \\
\hline Household Income & 28720 & 15899 & 37279 & 21274 & 26138 & 15248 & 35810 & 21016 \\
\hline Living in the South & 0.270 & 0.444 & 0.255 & 0.436 & 0.303 & 0.460 & 0.293 & 0.455 \\
\hline Living in Urban Area & 0.720 & 0.449 & 0.815 & 0.388 & 0.744 & 0.436 & 0.795 & 0.404 \\
\hline Not Living with Both Parents & 0.091 & 0.287 & 0.081 & 0.273 & 0.105 & 0.306 & 0.087 & 0.282 \\
\hline $\mathrm{N}$ & \multicolumn{2}{|c|}{1832} & \multicolumn{2}{|c|}{1246} & \multicolumn{2}{|c|}{1895} & \multicolumn{2}{|c|}{1354} \\
\hline
\end{tabular}

Note: The numbers in the table are means of the row variables, conditional on column segments of the sample. Age, education, and school enrollment are taken from the 1985 wave. Family size and household income are the three-year averages for 1978, 1979, and 1980. Information on the place of residence (region and urban area) and whether or not the respondents live with both parents was taken when the respondents were age 14. 
Table 2: Comparison of Means and Standard Deviations of Selected Variables of Parents

Sample: Fathers

\begin{tabular}{l|cc|cc|cc|cc|} 
& \multicolumn{9}{c|}{ Fathers } \\
\cline { 2 - 9 } & \multicolumn{2}{|c|}{$\begin{array}{c}\text { Less than High } \\
\text { School }\end{array}$} & \multicolumn{1}{c|}{ High School } & Some College & \multicolumn{2}{c|}{$\begin{array}{c}\text { More than } \\
\text { College }\end{array}$} \\
\cline { 2 - 9 } Variable & Mean & SD & Mean & SD & Mean & SD & Mean & SD \\
\hline Age & 44.380 & 7.742 & 42.944 & 6.891 & 43.528 & 6.101 & 44.215 & 6.100 \\
Education & 8.254 & 2.430 & 12.000 & 0.000 & 13.884 & 0.654 & 17.083 & 1.472 \\
Work for Pay & 0.915 & 0.280 & 0.977 & 0.151 & 0.969 & 0.173 & 0.984 & 0.126 \\
Average of All DOT People Skills & & & & & & & & \\
Relation to People & -0.524 & 0.730 & -0.235 & 0.857 & 0.135 & 0.924 & 0.573 & 0.871 \\
Deal with People & -0.325 & 0.747 & -0.022 & 0.791 & 0.304 & 0.740 & 0.852 & 0.605 \\
Talking and/or Hearing & -0.476 & 0.736 & -0.214 & 0.830 & 0.072 & 0.855 & 0.409 & 0.755 \\
Communicate Data & -0.459 & 0.760 & -0.159 & 0.815 & 0.168 & 0.804 & 0.495 & 0.626 \\
Business Contact & -0.492 & 0.630 & -0.237 & 0.766 & 0.138 & 0.826 & 0.552 & 0.734 \\
Work for Good of People & -0.247 & 0.656 & -0.062 & 0.784 & 0.065 & 0.951 & -0.146 & 1.107 \\
Interpret Feelings & -0.628 & 0.603 & -0.502 & 0.665 & -0.200 & 0.717 & 0.303 & 0.885 \\
Influence People & -0.061 & 0.562 & -0.069 & 0.469 & 0.019 & 0.803 & 0.132 & 1.037 \\
Math & -0.198 & 0.502 & -0.029 & 0.756 & 0.181 & 0.935 & 0.558 & 1.122 \\
Reasoning & -0.149 & 0.805 & 0.168 & 0.764 & 0.465 & 0.771 & 0.986 & 0.570 \\
Language & -0.207 & 0.718 & 0.124 & 0.680 & 0.485 & 0.703 & 1.074 & 0.551 \\
Verbal & -0.337 & 0.674 & -0.007 & 0.675 & 0.399 & 0.720 & 1.045 & 0.549 \\
Relation to Data & -0.382 & 0.720 & -0.028 & 0.732 & 0.403 & 0.777 & 1.062 & 0.547 \\
Relation to Things & -0.116 & 0.880 & 0.245 & 0.819 & 0.577 & 0.766 & 1.025 & 0.500 \\
Strength & 0.352 & 0.794 & 0.251 & 0.886 & -0.052 & 0.867 & -0.225 & 0.908 \\
N & 0.581 & 0.693 & 0.308 & 0.793 & -0.126 & 0.864 & -0.564 & 0.585 \\
\hline
\end{tabular}

Sample: Mothers

\begin{tabular}{|c|c|c|c|c|c|c|c|c|}
\hline \multirow[b]{3}{*}{ Variable } & \multicolumn{8}{|c|}{ Mothers } \\
\hline & \multicolumn{2}{|c|}{$\begin{array}{c}\text { Less than High } \\
\text { School }\end{array}$} & \multicolumn{2}{|c|}{ High School } & \multicolumn{2}{|c|}{ Some College } & \multicolumn{2}{|c|}{$\begin{array}{c}\text { More than } \\
\text { College }\end{array}$} \\
\hline & Mean & SD & Mean & SD & Mean & SD & Mean & SD \\
\hline$\overline{\text { Age }}$ & 40.367 & 6.664 & 40.737 & 6.056 & 41.577 & 5.927 & 42.765 & 6.038 \\
\hline Education & 8.745 & 2.329 & 12.000 & 0.000 & 13.856 & 0.695 & 16.452 & 0.915 \\
\hline Work for Pay & 0.466 & 0.499 & 0.535 & 0.499 & 0.543 & 0.498 & 0.605 & 0.489 \\
\hline \multicolumn{9}{|l|}{ DOT Variables } \\
\hline Average of All DOT People Skills & -0.193 & 0.793 & 0.192 & 0.802 & 0.372 & 0.696 & 0.858 & 0.655 \\
\hline Relation to People & -0.455 & 0.666 & -0.059 & 0.706 & 0.088 & 0.684 & 0.833 & 0.791 \\
\hline Deal with People & -0.089 & 0.903 & 0.237 & 0.867 & 0.476 & 0.775 & 0.764 & 0.556 \\
\hline Talking, Hearing & -0.183 & 0.894 & 0.181 & 0.840 & 0.438 & 0.720 & 0.682 & 0.508 \\
\hline Communicate Data & -0.204 & 0.759 & 0.240 & 0.845 & 0.509 & 0.739 & 0.973 & 0.621 \\
\hline Business Contact & 0.077 & 0.776 & 0.361 & 0.840 & 0.059 & 1.068 & -0.190 & 0.898 \\
\hline Work for Good of People & 0.060 & 0.836 & 0.208 & 0.748 & 0.549 & 0.846 & 1.073 & 0.742 \\
\hline Interpret Feelings & -0.031 & 0.500 & -0.021 & 0.576 & -0.025 & 0.699 & 0.305 & 1.355 \\
\hline Influence People & -0.237 & 0.421 & -0.088 & 0.636 & -0.046 & 0.666 & 0.291 & 0.916 \\
\hline Math & -0.618 & 0.659 & -0.110 & 0.719 & 0.288 & 0.717 & 0.534 & 0.570 \\
\hline Reasoning & -0.663 & 0.659 & -0.144 & 0.716 & 0.329 & 0.767 & 0.971 & 0.637 \\
\hline Language & -0.628 & 0.680 & -0.077 & 0.786 & 0.423 & 0.808 & 1.046 & 0.615 \\
\hline Verbal & -0.572 & 0.745 & 0.031 & 0.839 & 0.470 & 0.776 & 0.992 & 0.549 \\
\hline Relation to Data & -0.619 & 0.651 & -0.206 & 0.633 & 0.064 & 0.593 & 0.588 & 0.567 \\
\hline Relation to Things & -0.126 & 0.726 & 0.046 & 0.782 & 0.018 & 0.741 & -0.392 & 0.721 \\
\hline Strength & 0.042 & 0.682 & -0.431 & 0.792 & -0.454 & 0.858 & -0.434 & 0.636 \\
\hline $\mathrm{N}$ & \multicolumn{2}{|c|}{1546} & \multicolumn{2}{|c|}{2349} & \multicolumn{2}{|c|}{554} & \multicolumn{2}{|c|}{499} \\
\hline
\end{tabular}


Table 3: Effect of Mothers' Sociability on Children's Sociability: NLSY Female Respondents and Their Children

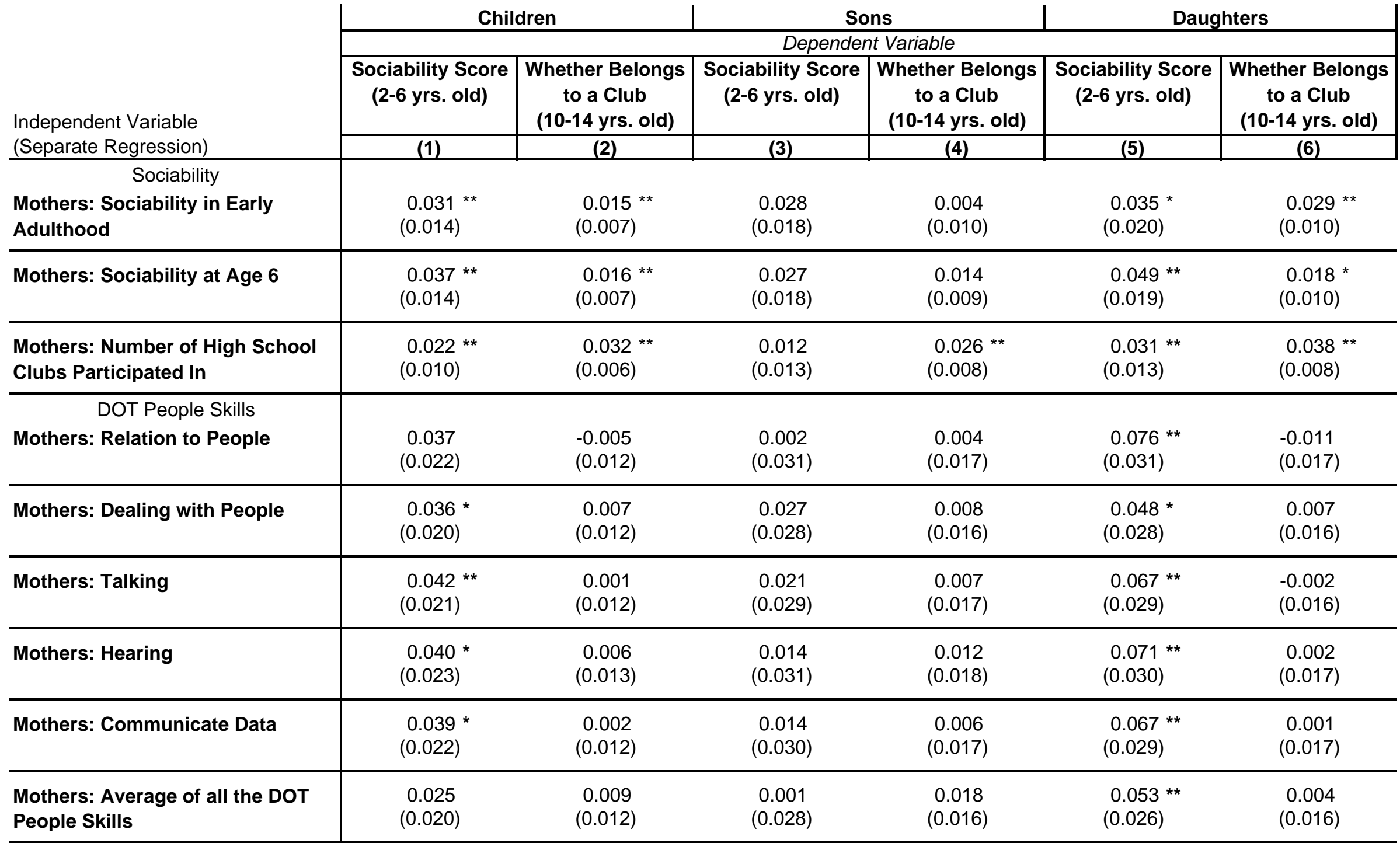

Note: Each estimate represents the coefficient from a different regression. The column headings identify the dependent variable, and the row headings indicate the independent variable used. Regressions in columns 1, 3, and 5 are estimated by OLS, and regressions in columns 2, 4, and 6 are estimated by probit. For this analysis of the sample of NLSY females and their children, mothers' self-reported sociability at age 6 and early adulthood is standardized to have within-sample mean zero and variance one, and children's

sociability is age-standardized. The mothers' DOT people skills are taken from the revised fourth edition of the DOT (1991), whose data were collected between 1978 and 1990 , a time span that overlaps with the years (1986-2000) for which the NLSY79 information on mothers' occupation is available. Note that "talking and/or hearing" in DOT (1977) is separated into two variables "talking" and "hearing" in DOT (1991), and "communicate data" is not available in DOT (1991), so for this variable DOT (1977) is used. Regressions control for mothers' education, a quadratic in mothers' AFQT score, mothers' age and children's age, mothers' marital status, place of residence (region and urban area), threeyear averages of family size and household income in 1983-1985, and year dummies. Robust standard errors clustered by mothers are in parentheses. Coefficients significant at the 5 percent level are indicated with two asterisks; one asterisk indicates significance at the 10 percent level. 
Table 4: Effect of Parents' People Skills on Children's Sociability: Approach I

Panel A: Using the textual definitions of the DOT variables, construction of skill types: people-skill index, cognitive-skill index, motor-skill index, and physical-strength index.

\begin{tabular}{|c|c|c|c|c|c|c|}
\hline \multirow[b]{3}{*}{ Fathers' Variable } & \multicolumn{2}{|c|}{ Father-Child } & \multicolumn{2}{|c|}{ Father-Son } & \multicolumn{2}{|c|}{ Father-Daughter } \\
\hline & $\begin{array}{c}\text { Sociability in } \\
\text { Early Adulthood }\end{array}$ & $\begin{array}{c}\text { Sociability at } \\
\text { Age } 6\end{array}$ & $\begin{array}{c}\text { Sociability in } \\
\text { Early Adulthood }\end{array}$ & $\begin{array}{c}\text { Sociability at } \\
\text { Age } 6 \\
\end{array}$ & $\begin{array}{c}\text { Sociability in } \\
\text { Early Adulthood }\end{array}$ & $\begin{array}{c}\text { Sociability at } \\
\text { Age } 6\end{array}$ \\
\hline & (1) & $(2)$ & (3) & (4) & (5) & $(6)$ \\
\hline People-Skill Index & $\begin{array}{c}0.039 \\
(0.031)\end{array}$ & $\begin{array}{c}0.024 \\
(0.030)\end{array}$ & $\begin{array}{l}0.100 \text { ** } \\
(0.046)\end{array}$ & $\begin{array}{c}0.052 \\
(0.044)\end{array}$ & $\begin{array}{l}-0.011 \\
(0.043)\end{array}$ & $\begin{array}{c}0.002 \\
(0.041)\end{array}$ \\
\hline Cognitive-Skill Index & $\begin{array}{c}0.007 \\
(0.028)\end{array}$ & $\begin{array}{c}0.039 \\
(0.028)\end{array}$ & $\begin{array}{l}-0.043 \\
(0.041)\end{array}$ & $\begin{array}{c}0.001 \\
(0.040)\end{array}$ & $\begin{array}{c}0.049 \\
(0.040)\end{array}$ & $\begin{array}{l}0.067 \text { * } \\
(0.038)\end{array}$ \\
\hline Motor-Skill Index & $\begin{array}{l}-0.016 \\
(0.027)\end{array}$ & $\begin{array}{l}-0.042 \\
(0.026)\end{array}$ & $\begin{array}{c}0.029 \\
(0.040)\end{array}$ & $\begin{array}{c}0.008 \\
(0.038)\end{array}$ & $\begin{array}{l}-0.051 \\
(0.037)\end{array}$ & $\begin{array}{l}-0.084 \text { ** } \\
(0.037)\end{array}$ \\
\hline Physical-Strength Index & $\begin{array}{c}0.009 \\
(0.032)\end{array}$ & $\begin{array}{c}0.027 \\
(0.031)\end{array}$ & $\begin{array}{c}0.013 \\
(0.047)\end{array}$ & $\begin{array}{c}0.030 \\
(0.045)\end{array}$ & $\begin{array}{c}0.006 \\
(0.045)\end{array}$ & $\begin{array}{c}0.021 \\
(0.044)\end{array}$ \\
\hline Father's Education & $\begin{array}{c}0.001 \\
(0.006)\end{array}$ & $\begin{array}{l}0.021 \text { ** } \\
(0.006)\end{array}$ & $\begin{array}{l}-0.002 \\
(0.008)\end{array}$ & $\begin{array}{l}0.029 * * \\
(0.008)\end{array}$ & $\begin{array}{c}0.004 \\
(0.008)\end{array}$ & $\begin{array}{l}0.014 \text { * } \\
(0.008)\end{array}$ \\
\hline Log likelihood & -4996.5 & -6240.6 & -2377.3 & -2929.8 & -2605.0 & -3291.6 \\
\hline $\mathrm{N}$ & 4991 & 4982 & 2408 & 2401 & 2583 & 2581 \\
\hline \multirow[b]{3}{*}{ Mothers' Variable } & \multicolumn{2}{|c|}{ Mother-Child } & \multicolumn{2}{|c|}{ Mother-Son } & \multicolumn{2}{|c|}{ Mother-Daughter } \\
\hline & $\begin{array}{c}\text { Sociability in } \\
\text { Early Adulthood }\end{array}$ & $\begin{array}{c}\text { Sociability at } \\
\text { Age } 6\end{array}$ & $\begin{array}{c}\text { Sociability in } \\
\text { Early Adulthood }\end{array}$ & $\begin{array}{c}\text { Sociability at } \\
\text { Age } 6\end{array}$ & $\begin{array}{c}\text { Sociability in } \\
\text { Early Adulthood }\end{array}$ & $\begin{array}{c}\text { Sociability at } \\
\text { Age } 6\end{array}$ \\
\hline & $(1)$ & $(2)$ & (3) & $(4)$ & $(5)$ & $(6)$ \\
\hline People-Skill Index & $\begin{array}{c}0.041 \\
(0.026)\end{array}$ & $\begin{array}{c}0.032 \\
(0.025)\end{array}$ & $\begin{array}{c}0.046 \\
(0.038)\end{array}$ & $\begin{array}{c}0.008 \\
(0.036)\end{array}$ & $\begin{array}{c}0.032 \\
(0.036)\end{array}$ & $\begin{array}{c}0.050 \\
(0.034)\end{array}$ \\
\hline Cognitive-Skill Index & $\begin{array}{c}0.034 \\
(0.031)\end{array}$ & $\begin{array}{c}0.021 \\
(0.030)\end{array}$ & $\begin{array}{c}0.029 \\
(0.045)\end{array}$ & $\begin{array}{c}0.068 \\
(0.044)\end{array}$ & $\begin{array}{c}0.037 \\
(0.042)\end{array}$ & $\begin{array}{l}-0.020 \\
(0.041)\end{array}$ \\
\hline Motor-Skill Index & $\begin{array}{c}0.020 \\
(0.020)\end{array}$ & $\begin{array}{l}0.041 \text { ** } \\
(0.019)\end{array}$ & $\begin{array}{c}0.006 \\
(0.029)\end{array}$ & $\begin{array}{c}0.021 \\
(0.028)\end{array}$ & $\begin{array}{c}0.031 \\
(0.028)\end{array}$ & $\begin{array}{l}0.059 \text { ** } \\
(0.027)\end{array}$ \\
\hline Physical-Strength Index & $\begin{array}{l}-0.024 \\
(0.025)\end{array}$ & $\begin{array}{l}-0.035 \\
(0.023)\end{array}$ & $\begin{array}{l}-0.035 \\
(0.037)\end{array}$ & $\begin{array}{l}-0.033 \\
(0.033)\end{array}$ & $\begin{array}{l}-0.014 \\
(0.033)\end{array}$ & $\begin{array}{l}-0.042 \\
(0.033)\end{array}$ \\
\hline Mother's Education & $\begin{array}{l}-0.003 \\
(0.009)\end{array}$ & $\begin{array}{c}0.001 \\
(0.008)\end{array}$ & $\begin{array}{l}-0.016 \\
(0.012)\end{array}$ & $\begin{array}{l}-0.004 \\
(0.012)\end{array}$ & $\begin{array}{c}0.010 \\
(0.012)\end{array}$ & $\begin{array}{c}0.004 \\
(0.011)\end{array}$ \\
\hline Log likelihood & -3696.6 & -4653.9 & -1744.9 & -2123.0 & -1938.9 & -2514.5 \\
\hline $\mathrm{N}$ & 3695 & 3691 & 1741 & 1739 & 1954 & 1952 \\
\hline
\end{tabular}

Note: All regressions are estimated by ordered probit, and control for children's education, a quadratic in the children's AFQT score, children's age and parents' age, parents' education, dummies for not living with both parents and for place of residence (region and urban area) when the children are age 14, and three-year averages of family size and household income in childhood. Coefficients significant at the 5 percent level are indicated with two asterisks; one asterisk indicates significance at the 10 percent level. 
Table 4: Effect of Parents' People Skills on Children's Sociability: Approach I (continued)

Panel B: Factor analysis to extract latent factors from the DOT variables.

\begin{tabular}{|c|c|c|c|c|c|c|}
\hline \multirow[b]{3}{*}{ Fathers' Variable } & \multicolumn{2}{|c|}{ Father-Child } & \multicolumn{2}{|c|}{ Father-Son } & \multicolumn{2}{|c|}{ Father-Daughter } \\
\hline & $\begin{array}{c}\text { Sociability in } \\
\text { Early Adulthood }\end{array}$ & $\begin{array}{l}\text { Sociability at } \\
\text { Age } 6\end{array}$ & $\begin{array}{c}\text { Sociability in } \\
\text { Early Adulthood }\end{array}$ & $\begin{array}{c}\text { Sociability at } \\
\text { Age } 6\end{array}$ & $\begin{array}{c}\text { Sociability in } \\
\text { Early Adulthood }\end{array}$ & $\begin{array}{c}\text { Sociability at } \\
\text { Age } 6\end{array}$ \\
\hline & (1) & (2) & (3) & (4) & (5) & (6) \\
\hline $1^{\text {st }}$ Factor: Cognitive Skills & $\begin{array}{c}0.016 \\
(0.020)\end{array}$ & $\begin{array}{c}0.027 \\
(0.019)\end{array}$ & $\begin{array}{c}0.003 \\
(0.029)\end{array}$ & $\begin{array}{c}0.011 \\
(0.028)\end{array}$ & $\begin{array}{c}0.027 \\
(0.027)\end{array}$ & $\begin{array}{c}0.038 \\
(0.026)\end{array}$ \\
\hline $2^{\text {nd }}$ Factor: Motor Skills & $\begin{array}{l}-0.033 * * \\
(0.016)\end{array}$ & $\begin{array}{l}-0.044 \text { ** } \\
(0.015)\end{array}$ & $\begin{array}{l}-0.016 \\
(0.023)\end{array}$ & $\begin{array}{l}-0.005 \\
(0.022)\end{array}$ & $\begin{array}{l}-0.045 * * \\
(0.022)\end{array}$ & $\begin{array}{l}-0.078 \text { ** } \\
(0.022)\end{array}$ \\
\hline $3^{\text {rd }}$ Factor: Physical Strength & $\begin{array}{l}-0.026 \\
(0.018)\end{array}$ & $\begin{array}{l}-0.015 \\
(0.017)\end{array}$ & $\begin{array}{l}-0.028 \\
(0.026)\end{array}$ & $\begin{array}{l}-0.004 \\
(0.025)\end{array}$ & $\begin{array}{l}-0.025 \\
(0.025)\end{array}$ & $\begin{array}{l}-0.025 \\
(0.024)\end{array}$ \\
\hline $4^{\text {th }}$ Factor: People Skills & $\begin{array}{l}-0.007 \\
(0.016)\end{array}$ & $\begin{array}{c}0.000 \\
(0.015)\end{array}$ & $\begin{array}{c}0.008 \\
(0.023)\end{array}$ & $\begin{array}{l}-0.001 \\
(0.022)\end{array}$ & $\begin{array}{l}-0.022 \\
(0.021)\end{array}$ & $\begin{array}{c}0.003 \\
(0.021)\end{array}$ \\
\hline $5^{\text {th }}$ Factor: People Skills & $\begin{array}{l}0.029 \text { * } \\
(0.015)\end{array}$ & $\begin{array}{c}0.022 \\
(0.015)\end{array}$ & $\begin{array}{l}0.059 * * \\
(0.022)\end{array}$ & $\begin{array}{l}0.039 \text { * } \\
(0.021)\end{array}$ & $\begin{array}{c}0.006 \\
(0.022)\end{array}$ & $\begin{array}{c}0.008 \\
(0.021)\end{array}$ \\
\hline Father's Education & $\begin{array}{c}0.002 \\
(0.006)\end{array}$ & $\begin{array}{l}0.021 \text { ** } \\
(0.006)\end{array}$ & $\begin{array}{l}-0.003 \\
(0.009)\end{array}$ & $\begin{array}{l}0.029 * * \\
(0.009)\end{array}$ & $\begin{array}{c}0.005 \\
(0.008)\end{array}$ & $\begin{array}{l}0.015 \text { * } \\
(0.008)\end{array}$ \\
\hline $\begin{array}{l}\text { Log likelihood } \\
\mathrm{N}\end{array}$ & $\begin{array}{c}-4994.9 \\
4991 \\
\end{array}$ & $\begin{array}{c}-6239.7 \\
4982 \\
\end{array}$ & $\begin{array}{c}-2376.0 \\
2408 \\
\end{array}$ & $\begin{array}{c}-2928.9 \\
2401 \\
\end{array}$ & $\begin{array}{c}-2604.0 \\
2583 \\
\end{array}$ & $\begin{array}{c}-3291.4 \\
2581 \\
\end{array}$ \\
\hline & \multicolumn{2}{|c|}{ Mother-Child } & \multicolumn{2}{|c|}{ Mother-Son } & \multicolumn{2}{|c|}{ Mother-Daughter } \\
\hline & $\begin{array}{c}\text { Sociability in } \\
\text { Early Adulthood }\end{array}$ & $\begin{array}{c}\text { Sociability at } \\
\text { Age } 6\end{array}$ & $\begin{array}{c}\text { Sociability in } \\
\text { Early Adulthood }\end{array}$ & $\begin{array}{c}\text { Sociability at } \\
\text { Age } 6\end{array}$ & $\begin{array}{c}\text { Sociability in } \\
\text { Early Adulthood }\end{array}$ & $\begin{array}{c}\text { Sociability at } \\
\text { Age } 6\end{array}$ \\
\hline Mothers' Variable & (1) & (2) & (3) & $(4)$ & (5) & (6) \\
\hline $1^{\text {st }}$ Factor: Cognitive Skills & $\begin{array}{l}0.078^{\text {** }} \\
(0.022)\end{array}$ & $\begin{array}{l}0.062 \text { ** } \\
(0.022)\end{array}$ & $\begin{array}{l}0.079^{\star \star} \\
(0.033)\end{array}$ & $\begin{array}{l}0.089^{\star \star} \\
(0.032)\end{array}$ & $\begin{array}{l}0.073^{* *} \\
(0.031)\end{array}$ & $\begin{array}{c}0.042 \\
(0.029)\end{array}$ \\
\hline $2^{\text {nd }}$ Factor: Motor Skills & $\begin{array}{c}0.015 \\
(0.018)\end{array}$ & $\begin{array}{l}0.047 \text { ** } \\
(0.017)\end{array}$ & $\begin{array}{l}-0.002 \\
(0.025)\end{array}$ & $\begin{array}{c}0.031 \\
(0.025)\end{array}$ & $\begin{array}{c}0.031 \\
(0.025)\end{array}$ & $\begin{array}{l}0.062 \text { ** } \\
(0.024)\end{array}$ \\
\hline $3^{\text {th }}$ Factor: People Skills & $\begin{array}{l}0.035 \text { * } \\
(0.019)\end{array}$ & $\begin{array}{l}0.038 \text { ** } \\
(0.018)\end{array}$ & $\begin{array}{c}0.039 \\
(0.028)\end{array}$ & $\begin{array}{c}0.029 \\
(0.026)\end{array}$ & $\begin{array}{c}0.025 \\
(0.026)\end{array}$ & $\begin{array}{l}0.043 \text { * } \\
(0.024)\end{array}$ \\
\hline $4^{\text {th }}$ Factor: Physical Strength & $\begin{array}{l}-0.027 \\
(0.018)\end{array}$ & $\begin{array}{l}-0.024 \\
(0.017)\end{array}$ & $\begin{array}{l}-0.031 \\
(0.027)\end{array}$ & $\begin{array}{l}-0.027 \\
(0.025)\end{array}$ & $\begin{array}{l}-0.026 \\
(0.024)\end{array}$ & $\begin{array}{l}-0.024 \\
(0.024)\end{array}$ \\
\hline Mother's Education & $\begin{array}{l}-0.004 \\
(0.009)\end{array}$ & $\begin{array}{c}0.003 \\
(0.008)\end{array}$ & $\begin{array}{l}-0.017 \\
(0.013)\end{array}$ & $\begin{array}{l}-0.002 \\
(0.012)\end{array}$ & $\begin{array}{c}0.010 \\
(0.012)\end{array}$ & $\begin{array}{c}0.007 \\
(0.012)\end{array}$ \\
\hline Log likelihood & -3694.6 & -4649.1 & -1743.8 & -2121.3 & -1937.3 & -2510.7 \\
\hline $\mathrm{N}$ & 3695 & 3691 & 1741 & 1739 & 1954 & 1952 \\
\hline
\end{tabular}


Dependent Variable:

\begin{tabular}{|c|c|c|c|c|c|c|}
\hline & \multicolumn{6}{|c|}{ Dependent Variable: } \\
\hline & $\begin{array}{c}\text { Sociability in } \\
\text { Early Adulthood }\end{array}$ & $\begin{array}{c}\text { Sociability at } \\
\text { Age } 6\end{array}$ & $\begin{array}{c}\text { Sociability in } \\
\text { Early Adulthood }\end{array}$ & $\begin{array}{c}\text { Sociability at } \\
\text { Age } 6\end{array}$ & $\begin{array}{c}\text { Sociability in } \\
\text { Early Adulthood }\end{array}$ & $\begin{array}{c}\text { Sociability at } \\
\text { Age } 6\end{array}$ \\
\hline & $(1)$ & $(2)$ & (3) & (4) & (5) & (6) \\
\hline \multicolumn{7}{|c|}{ Panel A: Parents' people skill without adjustment by DOT non-people skills } \\
\hline Independent Variables & \multicolumn{2}{|c|}{ Father-Child } & \multicolumn{2}{|c|}{ Father-Son } & \multicolumn{2}{|c|}{ Father-Daughter } \\
\hline Fathers' People-Skill & $0.047 \star \star$ & 0.049 ** & $0.053 * \star$ & 0.024 & 0.040 * & 0.072 ** \\
\hline Component & $(0.017)$ & $(0.017)$ & $(0.025)$ & $(0.024)$ & $(0.024)$ & $(0.024)$ \\
\hline \multirow[t]{2}{*}{ Fathers' Education } & 0.001 & $0.022 * *$ & -0.005 & $0.029 * *$ & 0.006 & $0.015 * *$ \\
\hline & $(0.006)$ & $(0.005)$ & $(0.008)$ & $(0.008)$ & $(0.008)$ & $(0.007)$ \\
\hline Log likelihood & -4996.7 & -6242.1 & -2378.2 & -2930.3 & -2606.2 & -3294.7 \\
\hline \multirow{2}{*}{$\mathrm{N}$} & 4991 & 4982 & 2408 & 2401 & 2583 & 2581 \\
\hline & \multicolumn{2}{|c|}{ Mother-Child } & \multicolumn{2}{|c|}{ Mother-Son } & \multicolumn{2}{|c|}{ Mother-Daughter } \\
\hline $\begin{array}{l}\text { Mothers' People-Skill } \\
\text { Component }\end{array}$ & $\begin{array}{l}0.055^{* *} \\
(0.020)\end{array}$ & $\begin{array}{c}0.025 \\
(0.020)\end{array}$ & $\begin{array}{l}0.060 * * \\
(0.030)\end{array}$ & $\begin{array}{c}0.025 \\
(0.029)\end{array}$ & $\begin{array}{c}0.046 \\
(0.028)\end{array}$ & $\begin{array}{c}0.024 \\
(0.027)\end{array}$ \\
\hline Mothers' Education & $\begin{array}{c}0.002 \\
(0.008)\end{array}$ & $\begin{array}{c}0.007 \\
(0.008)\end{array}$ & $\begin{array}{l}-0.010 \\
(0.012)\end{array}$ & $\begin{array}{c}0.006 \\
(0.012)\end{array}$ & $\begin{array}{c}0.015 \\
(0.011)\end{array}$ & $\begin{array}{c}0.008 \\
(0.011)\end{array}$ \\
\hline Log likelihood & -3700.9 & -4662.6 & -1746.9 & -2128.0 & -1941.4 & -2519.7 \\
\hline $\mathrm{N}$ & 3695 & 3691 & 1741 & 1739 & 1954 & 1952 \\
\hline \multicolumn{7}{|c|}{ Panel B: Parents' people skill with adjustment by DOT non-people skills, Approach II } \\
\hline Independent Variables & \multicolumn{2}{|c|}{ Father-Child } & \multicolumn{2}{|c|}{ Father-Son } & \multicolumn{2}{|c|}{ Father-Daughter } \\
\hline $\begin{array}{l}\text { Fathers' People-Skill } \\
\text { Component }\end{array}$ & $\begin{array}{l}0.037^{\star \star} \\
(0.016)\end{array}$ & $\begin{array}{c}0.007 \\
(0.016)\end{array}$ & $\begin{array}{l}0.085 * \star \\
(0.024)\end{array}$ & $\begin{array}{c}0.027 \\
(0.022)\end{array}$ & $\begin{array}{l}0.0002 \\
(0.022)\end{array}$ & $\begin{array}{l}-0.008 \\
(0.022)\end{array}$ \\
\hline Fathers' Education & $\begin{array}{c}0.002 \\
(0.006)\end{array}$ & $\begin{array}{l}0.021 * * \\
(0.006)\end{array}$ & $\begin{array}{l}-0.004 \\
(0.009)\end{array}$ & $\begin{array}{l}0.028 \\
(0.009)\end{array}$ & $\begin{array}{c}0.007 \\
(0.009)\end{array}$ & $\begin{array}{l}0.017^{* *} \\
(0.008)\end{array}$ \\
\hline Log likelihood & -4980.2 & -6218.4 & -2360.3 & -2914.4 & -2591.5 & -3276.6 \\
\hline \multirow[t]{2}{*}{$\mathrm{N}$} & 4991 & 4982 & 2408 & 2401 & 2583 & 2581 \\
\hline & \multicolumn{2}{|c|}{ Mother-Child } & \multicolumn{2}{|c|}{ Mother-Son } & \multicolumn{2}{|c|}{ Mother-Daughter } \\
\hline $\begin{array}{l}\text { Mothers' People-Skill } \\
\text { Component }\end{array}$ & $\begin{array}{c}0.020 \\
(0.018)\end{array}$ & $\begin{array}{c}0.016 \\
(0.017)\end{array}$ & $\begin{array}{l}-0.003 \\
(0.026)\end{array}$ & $\begin{array}{c}0.006 \\
(0.025)\end{array}$ & $\begin{array}{c}0.040 \\
(0.027)\end{array}$ & $\begin{array}{c}0.026 \\
(0.025)\end{array}$ \\
\hline Mothers' Education & $\begin{array}{c}0.001 \\
(0.009)\end{array}$ & $\begin{array}{c}0.004 \\
(0.009)\end{array}$ & $\begin{array}{l}-0.013 \\
(0.013)\end{array}$ & $\begin{array}{l}0.0002 \\
(0.013)\end{array}$ & $\begin{array}{c}0.016 \\
(0.012)\end{array}$ & $\begin{array}{c}0.006 \\
(0.012)\end{array}$ \\
\hline Log likelihood & -3684.8 & -4636.1 & -1736.0 & -2107.0 & -1928.6 & -2498.1 \\
\hline $\mathrm{N}$ & 3695 & 3691 & 1741 & 1739 & 1954 & 1952 \\
\hline
\end{tabular}


Sample: Father-Son

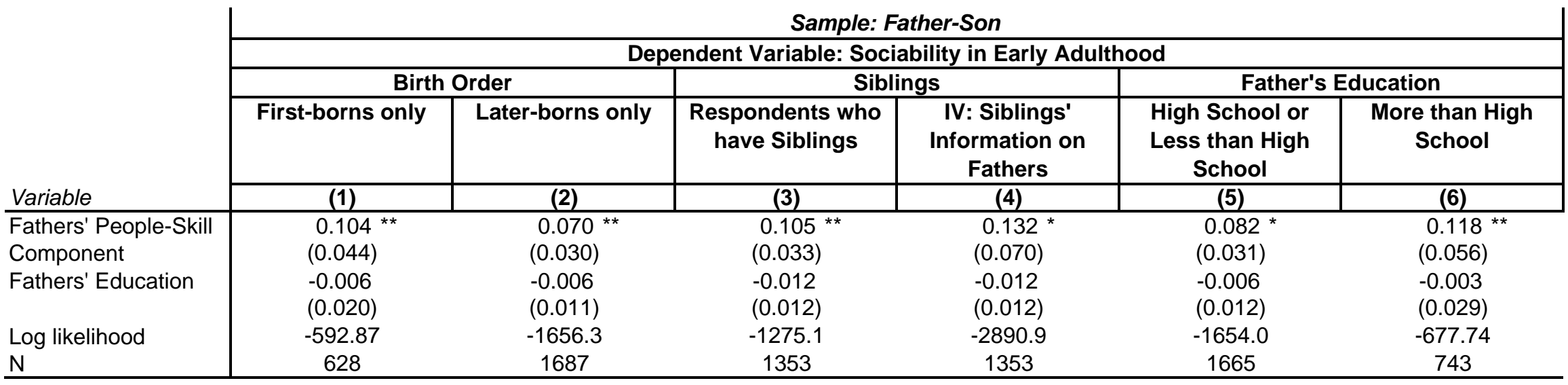

\begin{tabular}{|c|c|c|c|c|c|c|}
\hline \multirow[b]{4}{*}{ Variable } & \multicolumn{6}{|c|}{ Dependent Variable: Sociability at Age 6} \\
\hline & \multicolumn{2}{|c|}{ Birth Order } & \multicolumn{2}{|c|}{ Siblings } & \multicolumn{2}{|c|}{ Father's Education } \\
\hline & First-borns only & Later-borns only & $\begin{array}{l}\text { Respondents who } \\
\text { have Siblings }\end{array}$ & $\begin{array}{c}\text { IV: Siblings' } \\
\text { Information on } \\
\text { Fathers }\end{array}$ & $\begin{array}{l}\text { High School or } \\
\text { Less than High } \\
\text { School }\end{array}$ & $\begin{array}{c}\text { More than High } \\
\text { School }\end{array}$ \\
\hline & (1) & (2) & (3) & (4) & (5) & (6) \\
\hline $\begin{array}{l}\text { Fathers' People-Skill } \\
\text { Component }\end{array}$ & $\begin{array}{c}0.026 \\
(0.043)\end{array}$ & $\begin{array}{c}0.031 \\
(0.028)\end{array}$ & $\begin{array}{c}0.022 \\
(0.032)\end{array}$ & $\begin{array}{l}-0.003 \\
(0.067)\end{array}$ & $\begin{array}{c}0.013 \\
(0.028)\end{array}$ & $\begin{array}{l}0.131^{\star \star} \\
(0.053)\end{array}$ \\
\hline Fathers' Education & $\begin{array}{l}-0.001 \\
(0.020)\end{array}$ & $\begin{array}{l}0.034 \text { ** } \\
(0.010)\end{array}$ & $\begin{array}{c}0.013 \\
(0.012)\end{array}$ & $\begin{array}{c}0.013 \\
(0.011)\end{array}$ & $\begin{array}{l}0.033 \text { ** } \\
(0.012)\end{array}$ & $\begin{array}{l}0.050 \text { * } \\
(0.030)\end{array}$ \\
\hline Log likelihood & -736.07 & -2038.3 & -1603.5 & -3219.2 & -2011.9 & -869.29 \\
\hline $\mathrm{N}$ & 626 & 1683 & 1347 & 1347 & 1662 & 739 \\
\hline
\end{tabular}

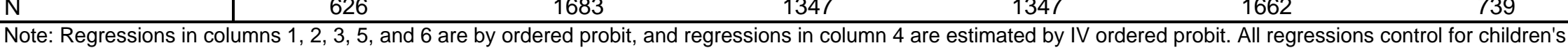
education, a quadratic in the children's AFQT score, children's age and parents' age, parents' education, dummies for not living with both parents and for place of residence (region and urban area) when the children are age 14, three-year averages of family size and household income in childhood, and non-people DOT variables used to adjust

DOT people skills. Coefficients significant at the 5 percent level are indicated with two asterisks; one asterisk indicates significance at the 10 percent level. 
Table 7: Effect of NLSY Respondents' Sociability on Their Wages

\section{Sample: NLSY Respondents}

\begin{tabular}{l|c|c|}
\cline { 2 - 3 } & \multicolumn{2}{c|}{ Sample } \\
\cline { 2 - 3 } Independent Variable & Men & Women \\
\cline { 2 - 3 } (Separate Regression) & $\mathbf{( 1 )}$ & $\mathbf{( 2 )}$ \\
\hline Sociability in Early Adulthood & 0.0164 ** & 0.0202 ** \\
Sociability at Age 6 & $(0.0066)$ & $0.0064)$ \\
& $0.0180^{* *}$ & $(0.0061)$ \\
No. of High School Clubs Participated In & $(0.0066)$ & $0.0096 * *$ \\
& $0.0249 * *$ & $(0.0048)$ \\
\hline
\end{tabular}

Note: Each estimate represents the coefficient from a different regression. This analysis uses the sample of NLSY respondents since 1985. Sociability at age 6 and in early adulthood is standardized to have mean zero and variance one. Regressions control for education, a quadratic in AFQT score and age, marital status, place of residence (region and urban area), and year dummies. Robust standard errors clustered by respondents are in parentheses.

Coefficients significant at the 5 percent level are indicated with two asterisks; one asterisk indicates significance at the 10 percent level. 
Appendix Table 1: Definitions of the Variables from the Dictionary of Occupational Titles (DOT)

\begin{tabular}{|c|c|c|}
\hline VARIABLE & $\begin{array}{c}\text { DOT JOB } \\
\text { COMPONENT }\end{array}$ & DESCRIPTION \\
\hline \multicolumn{3}{|c|}{ People-Skill Variables } \\
\hline Relation to People & Worker Function & $\begin{array}{l}\text { Complexity at which worker performs job in relation to people, from highest to lowest: } \\
\text { Mentoring, Negotiating, Instructing, Supervising, Diverting, Persuading, Speaking- } \\
\text { Signaling, Serving. Taking Instructions-Helping. }\end{array}$ \\
\hline Deal with People & Temperaments & Adaptability to dealing with people beyond giving and receiving instructions. \\
\hline Influence People & Temperaments & $\begin{array}{l}\text { Adaptability to influencing people in their opinions, attitudes or judgments about ideas or } \\
\text { things. }\end{array}$ \\
\hline Interpret Feelings & Temperaments & $\begin{array}{l}\text { Adaptability to situations involving the interpretation of feeling, ideas or facts in terms of } \\
\text { personal viewpoint. }\end{array}$ \\
\hline $\begin{array}{l}\text { Talking and/or } \\
\text { Hearing }\end{array}$ & $\begin{array}{l}\text { Physical } \\
\text { Demands }\end{array}$ & Presence or absence of talking and/or hearing. \\
\hline $\begin{array}{l}\text { Communicate } \\
\text { Data }\end{array}$ & Interest Factor & $\begin{array}{l}\text { A preference for activities concerned with the communication of data versus a } \\
\text { preference for activities for dealing with things and objects. }\end{array}$ \\
\hline Business Contact & Interest Factor & $\begin{array}{l}\text { A preference for activities involving business contact with people versus a preference for } \\
\text { activities of a scientific and technical nature. }\end{array}$ \\
\hline $\begin{array}{l}\text { Work for Good of } \\
\text { People }\end{array}$ & Interest Factor & $\begin{array}{l}\text { A preference for working for the presumed good of people versus a preference for } \\
\text { activities that are carried on in relation to processes, machines, and techniques. }\end{array}$ \\
\hline
\end{tabular}

\section{Non-People-Skill Variables}

\begin{tabular}{|c|c|c|}
\hline \multicolumn{3}{|r|}{ Cognitive-Skill Variables: } \\
\hline Relation to Data & Worker Function & $\begin{array}{l}\text { Complexity at which worker performs job in relation to data, from highest to lowest: } \\
\text { Synthesizing, Coordinating, Analyzing, Compiling, Computing, Copying, Comparing. }\end{array}$ \\
\hline Reasoning & GED & $\begin{array}{l}\text { General educational development (GED) in reasoning required for job, ranging from } \\
\text { being able to apply logical or scientific thinking to wide range of intellectual and practical } \\
\text { problems, to being able to apply commonsense understanding to carry out simple } \\
\text { instructions. }\end{array}$ \\
\hline Mathematics & GED & $\begin{array}{l}\text { GED in mathematics required for job, from knowledge of advanced calculus, modern } \\
\text { algebra and statistics; algebra, geometry and shop math; to simple addition and } \\
\text { subtraction. }\end{array}$ \\
\hline Language & GED & $\begin{array}{l}\text { GED in language required for job, from reading literature, writing editorials and } \\
\text { speeches, and conversant in persuasive speaking and debate; to reading at rate of 95- } \\
120 \text { words per minute or vocabulary of } 2500 \text { words and writing and speaking simple } \\
\text { sentences. }\end{array}$ \\
\hline $\begin{array}{l}\text { Specific } \\
\text { Vocational } \\
\text { Preparation }\end{array}$ & SVP & $\begin{array}{l}\text { SVP is the amount of time required to learn the techniques, acquire the information, and } \\
\text { develop the facility needed for average performance in a specific job-worker situation. }\end{array}$ \\
\hline General Learning & Aptitude & $\begin{array}{l}\text { Ability to "catch on" or understand instructions and underlying principles; ability to reason } \\
\text { and make judgments. }\end{array}$ \\
\hline Verbal & Aptitude & $\begin{array}{l}\text { Ability to understand meaning of words and to use them effectively. Ability to } \\
\text { comprehend language, to understand relationships between words, and to understand } \\
\text { meanings of whole sentences and paragraphs. }\end{array}$ \\
\hline Numerical & Aptitude & Ability to perform arithmetic operations quickly and accurately. \\
\hline $\begin{array}{l}\text { Clerical } \\
\text { Perception }\end{array}$ & Aptitude & $\begin{array}{l}\text { Ability to perceive pertinent detail in verbal or tabular material. Ability to observe } \\
\text { differences in copy, to proofread words and numbers, and to avoid perceptual errors in } \\
\text { arithmetic computation. A measure of perception which is required in many industrial } \\
\text { jobs even when the job does not have verbal or numerical content. }\end{array}$ \\
\hline Plan Activity & Temperaments & Adaptability to accepting responsibility for the direction, control or planning of an activity. \\
\hline Make Evaluations & Temperaments & $\begin{array}{l}\text { Adaptability to making generalizations, evaluations, or decisions based on sensory or } \\
\text { judgmental criteria. }\end{array}$ \\
\hline Creative Activity & Interest Factor & $\begin{array}{l}\text { A preference for activities of an abstract and creative nature versus a preference for } \\
\text { activities of a routine, concrete, organized nature. }\end{array}$ \\
\hline Esteem of Others & Interest Factor & $\begin{array}{l}\text { A preference for activities resulting in prestige or the esteem of others versus a } \\
\text { preference for activities resulting in tangible productive satisfaction. }\end{array}$ \\
\hline
\end{tabular}


Appendix Table 1: Definitions of the Variables from the Dictionary of Occupational Titles (continued)

\begin{tabular}{|c|c|c|}
\hline VARIABLE & $\begin{array}{c}\text { DOT JOB } \\
\text { COMPONENT }\end{array}$ & DESCRIPTION \\
\hline Relation to Things & Worker Function & $\begin{array}{l}\quad \text { Motor-Skills Variables: } \\
\quad \text { Complexity at which worker performs job in relation to things: Setting-Up, Precision } \\
\text { Working, Operating-Controlling, Driving-Operating, Manipulating, Tending, Feeding- } \\
\text { Offbearing, Handling. }\end{array}$ \\
\hline Finger Dexterity & Aptitude & Ability to move fingers, and manipulate small objects with fingers, rapidly or accurately. \\
\hline $\begin{array}{l}\text { Motor } \\
\text { Coordination }\end{array}$ & Aptitude & $\begin{array}{l}\text { Ability to coordinate eyes and hands or fingers rapidly and accurately in making precise } \\
\text { movements with speed. Ability to make a movement response accurately and swiftly. }\end{array}$ \\
\hline Manual Dexterity & Aptitude & $\begin{array}{l}\text { Ability to move the hands easily and skillfully. Ability to work with the hands in placing } \\
\text { and turning motions. }\end{array}$ \\
\hline $\begin{array}{l}\text { Eye-Hand-Foot } \\
\text { Coordination }\end{array}$ & Aptitude & $\begin{array}{l}\text { Ability to move the hand and foot coordinately with each other in accordance with visual } \\
\text { stimuli. }\end{array}$ \\
\hline Spatial Perception & Aptitude & $\begin{array}{l}\text { Ability to think visually of geometric forms and to comprehend the two-dimensional } \\
\text { representation of three-dimensional objects. Ability to recognize the relationships } \\
\text { resulting from the movement of objects in space. }\end{array}$ \\
\hline Form Perception & Aptitude & $\begin{array}{l}\text { Ability to perceive pertinent detail in objects or in pictorial or graphic material. Ability to } \\
\text { make visual comparisons and discriminations and see slight differences in shapes and } \\
\text { shadings of figures and widths and lengths of lines. }\end{array}$ \\
\hline $\begin{array}{l}\text { Color } \\
\text { Discrimination }\end{array}$ & Aptitude & $\begin{array}{l}\text { Ability to match or discriminate between colors in terms of hue, saturation, and brilliance. } \\
\text { Ability to identify a particular color or color combination from memory and to perceive } \\
\text { contrasting color combinations. }\end{array}$ \\
\hline $\begin{array}{l}\text { Precisely Set } \\
\text { Limits }\end{array}$ & Temperaments & $\begin{array}{l}\text { Adaptability to situations requiring the precise attainment of set limits, tolerances or } \\
\text { standards. }\end{array}$ \\
\hline Repetitive Work & Temperaments & $\begin{array}{l}\text { Adaptability to performing repetitive work, or to continuously performing the same work, } \\
\text { according to set procedures, sequence, or pace. }\end{array}$ \\
\hline Make Judgments & Temperaments & $\begin{array}{l}\text { Adaptability to making generalizations, judgments, or decisions based on measurable or } \\
\text { verifiable criteria. }\end{array}$ \\
\hline $\begin{array}{l}\text { Perform Variety of } \\
\text { Duties }\end{array}$ & Temperaments & $\begin{array}{l}\text { Adaptability to performing a variety of duties, often changing from one task to another of } \\
\text { a different nature without loss of efficiency or composure. }\end{array}$ \\
\hline Under Stress & Temperaments & $\begin{array}{l}\text { Adaptability to performing under stress when confronted with emergency, critical, } \\
\text { unusual, or dangerous situations; or in situations in which working speed and sustained } \\
\text { attention are make or break aspects of the job. }\end{array}$ \\
\hline & & Physical-Strength Variables: \\
\hline Strength & $\begin{array}{l}\text { Physical } \\
\text { Strength }\end{array}$ & $\begin{array}{l}\text { Strength Rating reflects the estimated overall strength requirement of the job (expressed } \\
\text { by: sedentary, light, medium, heavy, and very heavy). }\end{array}$ \\
\hline Climbing & $\begin{array}{l}\text { Physical } \\
\text { Strength }\end{array}$ & Indicate the presence or absence of climbing (climbing and/or balancing). \\
\hline Stooping & $\begin{array}{l}\text { Physical } \\
\text { Strength }\end{array}$ & $\begin{array}{l}\text { Indicate the presence or absence of stooping (stooping, kneeling, crouching, and/or } \\
\text { crawling). }\end{array}$ \\
\hline Reaching & $\begin{array}{l}\text { Physical } \\
\text { Strength }\end{array}$ & $\begin{array}{l}\text { Indicate the presence or absence of reaching (reaching, handling, fingering and/or } \\
\text { feeling). }\end{array}$ \\
\hline Seeing & $\begin{array}{l}\text { Physical } \\
\text { Strength }\end{array}$ & Indicate the presence or absence of seeing. \\
\hline
\end{tabular}

Note: Aptitudes (specific capacities or abilities required of an individual in order to facilitate the learning of some task or job duty) have been rated for each occupation, using a five-point scale. The quintiles for rating aptitudes are based on whether the segment of the population possessing the particular aptitude is within: the top 10 percent of the population, the top one-third except for the top 10 percent, the middle third, the lowest third except for the bottom 10 percent, and the lowest 10 percent. Temperaments are coded one for the presence and zero for the absence of a given temperament. Bipolar interest factors signify interests, tastes, and preferences for certain kinds of activities that are entailed in job performance; these interest factors are indicated by 1,0 , and -1 , respectively. 
Appendix Table 2: Effect of NLSY Respondents' Sociability on Their Job Characteristics

Sample: NLSY Respondents

\begin{tabular}{|c|c|c|c|}
\hline \multirow{3}{*}{$\begin{array}{l}\text { Dependent Variable } \\
\text { (Separate Regression) }\end{array}$} & \multicolumn{3}{|c|}{ Independent Variable } \\
\hline & $\begin{array}{c}\text { Sociability in } \\
\text { Early Adulthood }\end{array}$ & $\begin{array}{c}\text { Sociability at } \\
\text { Age } 6\end{array}$ & $\begin{array}{c}\text { No. of H.S. Clubs } \\
\text { Participated In }\end{array}$ \\
\hline & (1) & $(2)$ & (3) \\
\hline \multicolumn{4}{|l|}{ DOT People Skills } \\
\hline Dealing with People & $\begin{array}{l}0.041 \text { ** } \\
(0.007)\end{array}$ & $\begin{array}{l}0.033 \text { ** } \\
(0.007)\end{array}$ & $\begin{array}{l}0.030 \text { ** } \\
(0.006)\end{array}$ \\
\hline Talking & $\begin{array}{l}0.041 \text { ** } \\
(0.007)\end{array}$ & $\begin{array}{l}0.034 \text { ** } \\
(0.007)\end{array}$ & $\begin{array}{l}0.032 * * \\
(0.005)\end{array}$ \\
\hline Hearing & $\begin{array}{l}0.040 * * \\
(0.006)\end{array}$ & $\begin{array}{l}0.033 * * \\
(0.006)\end{array}$ & $\begin{array}{l}0.029 * * \\
(0.005)\end{array}$ \\
\hline Communicate Data & $\begin{array}{l}0.034 \text { ** } \\
(0.007)\end{array}$ & $\begin{array}{l}0.031 \text { ** } \\
(0.007)\end{array}$ & $\begin{array}{l}0.032 \text { ** } \\
(0.006)\end{array}$ \\
\hline Business Contact with People & $\begin{array}{l}0.056 \text { ** } \\
(0.008)\end{array}$ & $\begin{array}{l}0.040 * * \\
(0.008)\end{array}$ & $\begin{array}{l}0.024 * * \\
(0.007)\end{array}$ \\
\hline Work for Good of People & $\begin{array}{l}0.036 \text { ** } \\
(0.007)\end{array}$ & $\begin{array}{l}0.027 \text { ** } \\
(0.007)\end{array}$ & $\begin{array}{l}0.023 \text { ** } \\
(0.006)\end{array}$ \\
\hline Interpret Feelings & $\begin{array}{c}0.007 \\
(0.008)\end{array}$ & $\begin{array}{c}0.010 \\
(0.008)\end{array}$ & $\begin{array}{l}0.023 * * \\
(0.008)\end{array}$ \\
\hline Influencing People & $\begin{array}{l}0.028 * * \\
(0.006)\end{array}$ & $\begin{array}{l}0.028 * * \\
(0.006)\end{array}$ & $\begin{array}{l}0.025 * * \\
(0.006)\end{array}$ \\
\hline Relation to People & $\begin{array}{l}0.035 \text { ** } \\
(0.006)\end{array}$ & $\begin{array}{l}0.030 * * \\
(0.006)\end{array}$ & $\begin{array}{l}0.032 \text { ** } \\
(0.005)\end{array}$ \\
\hline Average of all the DOT People Skills & $\begin{array}{l}0.046 * * \\
(0.007)\end{array}$ & $\begin{array}{l}0.040 * * \\
(0.007)\end{array}$ & $\begin{array}{l}0.043 * * \\
(0.006)\end{array}$ \\
\hline People-Task of Borghans et al. (2006) & $\begin{array}{l}0.056 \text { ** } \\
(0.007)\end{array}$ & $\begin{array}{l}0.044 \text { ** } \\
(0.007)\end{array}$ & $\begin{array}{l}0.039 * * \\
(0.006)\end{array}$ \\
\hline
\end{tabular}

Note: Each estimate represents the coefficient from a different regression. The column headings identify the independent variable, and the row headings indicate the dependent variable used. This analysis uses the sample of NLSY respondents since 1985. Self-reported sociability at age 6 and in early adulthood is standardized to have mean zero and variance one. The DOT people skills are taken from the revised fourth edition of DOT (1991), whose data were collected between 1978 and 1990; a time span that overlaps with the years (1985-2000) for which the NLSY79 information on occupations is available. Note that "talking and/or hearing" in DOT (1977) is separated into two variables -- "talking" and "hearing" -- in DOT (1991); also, "communicate data," "business contact with people," and "work for good of people" are not available in DOT (1991), so for these three variables DOT (1977) is used. Regressions control for education, a quadratic in AFQT score and age; dummies for sex, marital status, and place of residence (region and urban area); three-year averages of family size and household income in childhood, and year dummies. Robust standard errors clustered by respondents are in parentheses. Coefficients significant at the 5 percent level are indicated with two asterisks; one asterisk indicates significance at the 10 percent level. 
Panel A: Father-Child

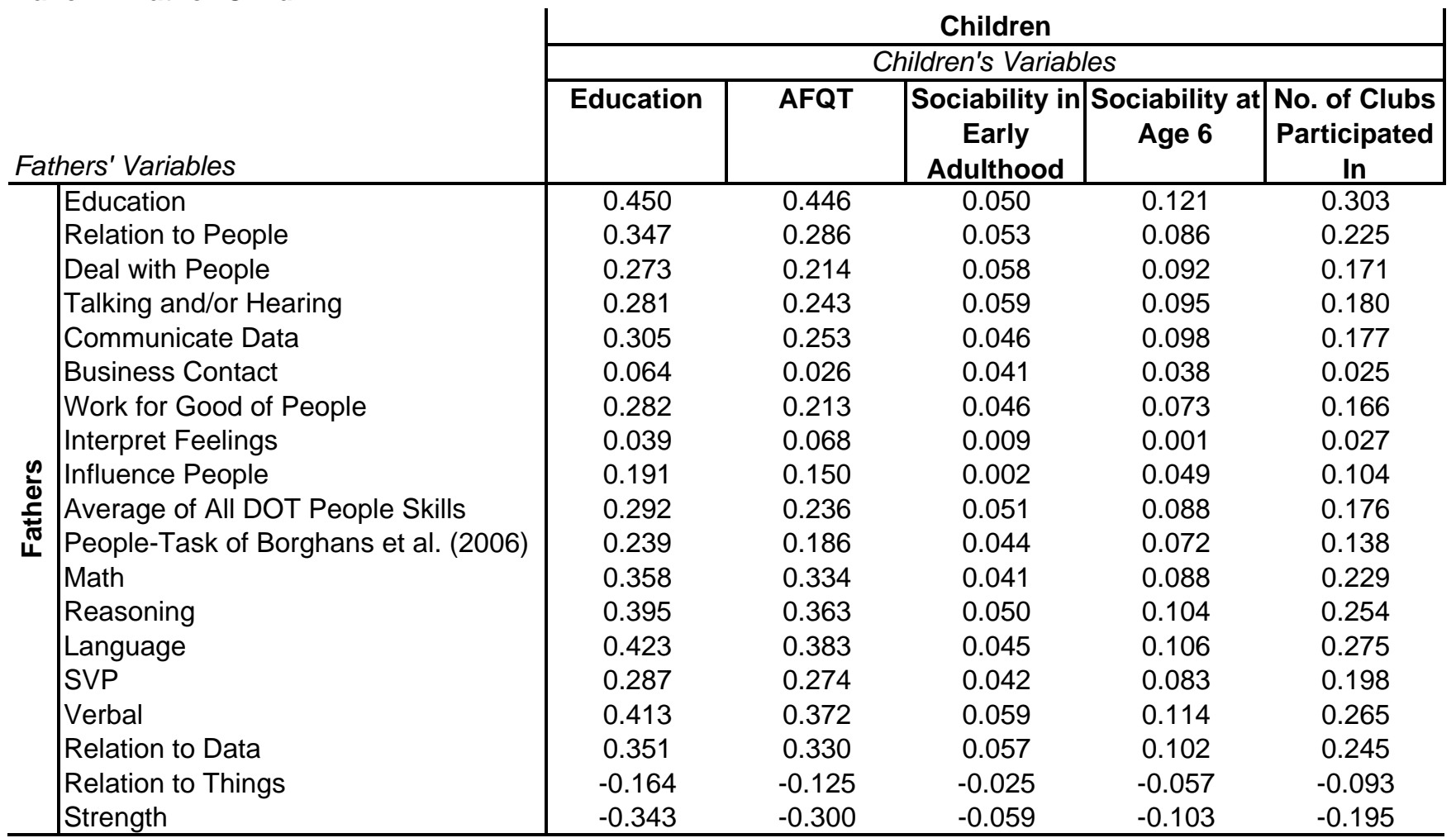

Panel B: Mother-Child

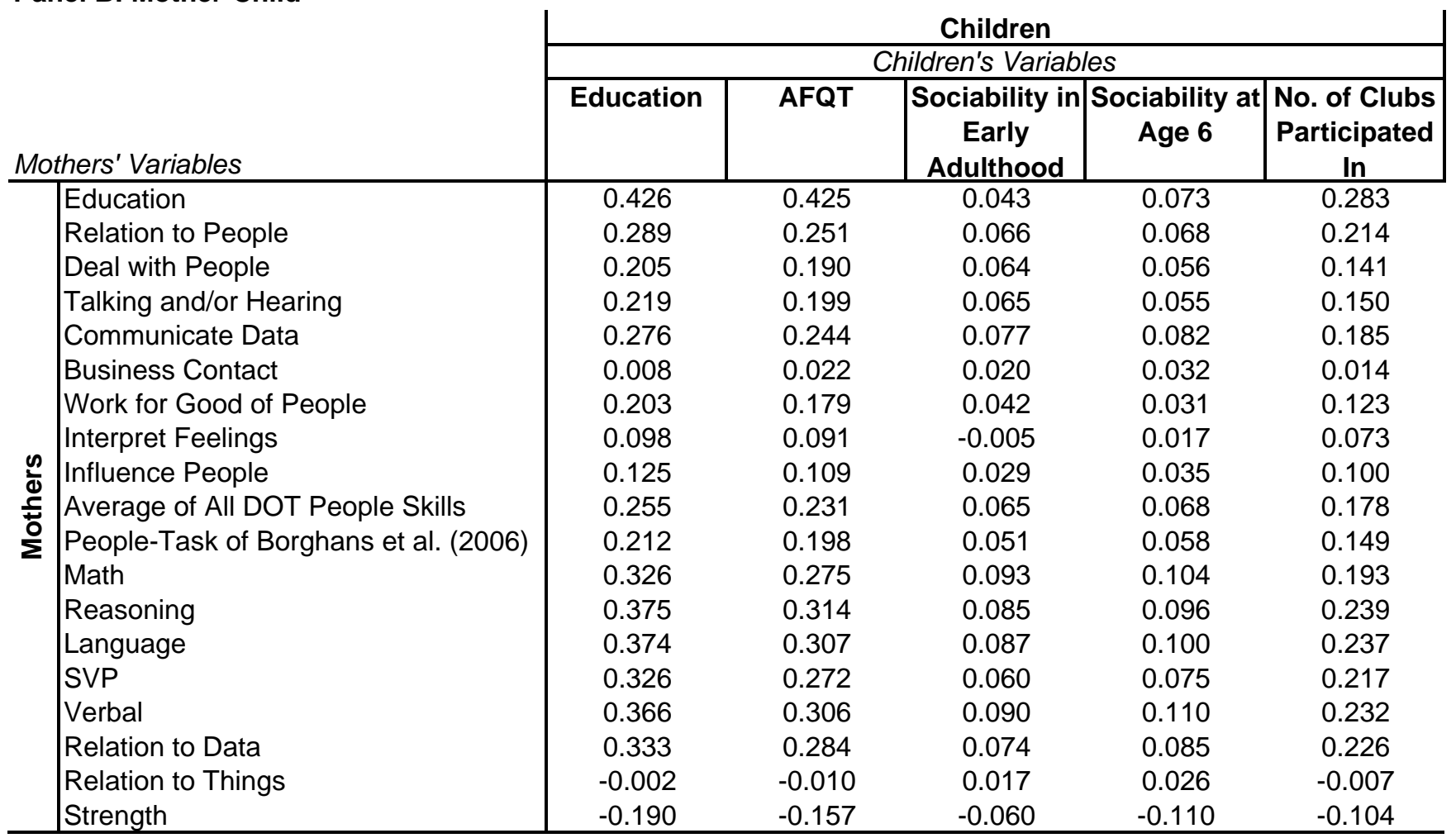

Note: Children's education level is taken from the 1985 wave. The DOT data are matched to parents' 1970 census occupation at the three-digit level. The number of observations is 5,600 for father-child pairs and 4,005 for mother-child pairs. 
Panel A: Father-Child

\begin{tabular}{|c|c|c|c|c|c|c|c|c|c|}
\hline \multirow{4}{*}{$\begin{array}{l}\text { Independent Variable } \\
\text { (Separate Regression) }\end{array}$} & \multicolumn{3}{|c|}{ Children } & \multicolumn{3}{|c|}{ Sons } & \multicolumn{3}{|c|}{ Daughters } \\
\hline & \multicolumn{9}{|c|}{ Dependent Variable } \\
\hline & \begin{tabular}{|c|}
$\begin{array}{c}\text { Sociability in } \\
\text { Early } \\
\text { Adulthood }\end{array}$ \\
\end{tabular} & $\begin{array}{c}\text { Sociability at } \\
\text { Age } 6\end{array}$ & \begin{tabular}{|c|} 
No. Clubs \\
Participated \\
In
\end{tabular} & \begin{tabular}{|c|}
$\begin{array}{c}\text { Sociability in } \\
\text { Early } \\
\text { Adulthood }\end{array}$ \\
\end{tabular} & $\begin{array}{c}\text { Sociability at } \\
\text { Age } 6\end{array}$ & $\begin{array}{c}\text { No. Clubs } \\
\text { Participated } \\
\text { In }\end{array}$ & $\begin{array}{c}\text { Sociability in } \\
\text { Early } \\
\text { Adulthood }\end{array}$ & $\begin{array}{c}\text { Sociability at } \\
\text { Age } 6\end{array}$ & $\begin{array}{c}\text { No. Clubs } \\
\text { Participated } \\
\text { In }\end{array}$ \\
\hline & $(1)$ & (2) & \begin{tabular}{|l|}
$(3)$ \\
\end{tabular} & $(4)$ & (5) & (6) & $(7)$ & (8) & $(9)$ \\
\hline Fathers & & & & & & & & & \\
\hline Dealing with People & $\begin{array}{l}0.057 * * \\
(0.020)\end{array}$ & $\begin{array}{l}0.062 * * \\
(0.020)\end{array}$ & $\begin{array}{c}0.011 \\
(0.020)\end{array}$ & $\begin{array}{l}0.066 * * \\
(0.029)\end{array}$ & $\begin{array}{c}0.029 \\
(0.028)\end{array}$ & $\begin{array}{c}0.026 \\
(0.029)\end{array}$ & $\begin{array}{l}0.051 * \\
(0.029)\end{array}$ & $\begin{array}{l}0.090 * * \\
(0.028)\end{array}$ & $\begin{array}{c}0.011 \\
(0.027)\end{array}$ \\
\hline Talking and/or Hearing & $\begin{array}{l}0.050 \text { ** } \\
(0.021)\end{array}$ & $\begin{array}{l}0.054 \text { ** } \\
(0.021)\end{array}$ & $\begin{array}{c}0.014 \\
(0.021)\end{array}$ & $\begin{array}{l}0.075 * * \\
(0.032)\end{array}$ & $\begin{array}{c}0.036 \\
(0.031)\end{array}$ & $\begin{array}{c}0.026 \\
(0.031)\end{array}$ & $\begin{array}{c}0.030 \\
(0.029)\end{array}$ & $\begin{array}{l}0.069 * * \\
(0.029)\end{array}$ & $\begin{array}{c}0.013 \\
(0.028)\end{array}$ \\
\hline Communicate Data & $\begin{array}{l}0.042 * \\
(0.022)\end{array}$ & $\begin{array}{l}0.064^{* *} \\
(0.021)\end{array}$ & $\begin{array}{l}-0.019 \\
(0.022)\end{array}$ & $\begin{array}{c}0.050 \\
(0.031)\end{array}$ & $\begin{array}{c}0.037 \\
(0.031)\end{array}$ & $\begin{array}{l}-0.008 \\
(0.032)\end{array}$ & $\begin{array}{c}0.034 \\
(0.030)\end{array}$ & $\begin{array}{l}0.090 * * \\
(0.030)\end{array}$ & $\begin{array}{l}-0.017 \\
(0.030)\end{array}$ \\
\hline Business Contact with People & $\begin{array}{l}0.056 \text { ** } \\
(0.019)\end{array}$ & $\begin{array}{l}0.049 * * \\
(0.018)\end{array}$ & $\begin{array}{c}0.009 \\
(0.018)\end{array}$ & $\begin{array}{l}0.061 \text { ** } \\
(0.027)\end{array}$ & $\begin{array}{c}0.031 \\
(0.025)\end{array}$ & $\begin{array}{l}-0.0005 \\
(0.026)\end{array}$ & $\begin{array}{l}0.048 \text { * } \\
(0.027)\end{array}$ & $\begin{array}{l}0.068 \text { ** } \\
(0.026)\end{array}$ & $\begin{array}{c}0.018 \\
(0.026)\end{array}$ \\
\hline Work for the Good of People & $\begin{array}{l}0.054 \text { ** } \\
(0.022)\end{array}$ & $\begin{array}{l}0.040 * \\
(0.021)\end{array}$ & $\begin{array}{l}-0.021 \\
(0.022)\end{array}$ & $\begin{array}{l}0.064 * * \\
(0.031)\end{array}$ & $\begin{array}{c}0.016 \\
(0.031)\end{array}$ & $\begin{array}{l}-0.009 \\
(0.031)\end{array}$ & $\begin{array}{c}0.046 \\
(0.030)\end{array}$ & $\begin{array}{l}0.061 * * \\
(0.030)\end{array}$ & $\begin{array}{l}-0.014 \\
(0.030)\end{array}$ \\
\hline Interpret Feelings & $\begin{array}{c}0.005 \\
(0.022)\end{array}$ & $\begin{array}{l}-0.019 \\
(0.020)\end{array}$ & $\begin{array}{l}-0.032 \\
(0.029)\end{array}$ & $\begin{array}{c}0.035 \\
(0.033)\end{array}$ & $\begin{array}{l}-0.007 \\
(0.030)\end{array}$ & $\begin{array}{c}0.040 \\
(0.042)\end{array}$ & $\begin{array}{l}-0.032 \\
(0.026)\end{array}$ & $\begin{array}{l}-0.033 \\
(0.025)\end{array}$ & $\begin{array}{l}-0.110 * * \\
(0.034)\end{array}$ \\
\hline Influencing People & $\begin{array}{l}-0.0001 \\
(0.019)\end{array}$ & $\begin{array}{c}0.022 \\
(0.019)\end{array}$ & $\begin{array}{l}-0.023 \\
(0.020)\end{array}$ & $\begin{array}{l}-0.002 \\
(0.027)\end{array}$ & $\begin{array}{c}0.009 \\
(0.028)\end{array}$ & $\begin{array}{l}-0.023 \\
(0.028)\end{array}$ & $\begin{array}{l}0.0002 \\
(0.027)\end{array}$ & $\begin{array}{c}0.035 \\
(0.027)\end{array}$ & $\begin{array}{l}-0.014 \\
(0.029)\end{array}$ \\
\hline Relation to People & $\begin{array}{l}0.056 \text { ** } \\
(0.022)\end{array}$ & $\begin{array}{l}0.048 \text { ** } \\
(0.021)\end{array}$ & $\begin{array}{c}0.028 \\
(0.021)\end{array}$ & $\begin{array}{c}0.037 \\
(0.032)\end{array}$ & $\begin{array}{c}0.001 \\
(0.031)\end{array}$ & $\begin{array}{c}0.020 \\
(0.031)\end{array}$ & $\begin{array}{l}0.074^{\star *} \\
(0.030)\end{array}$ & $\begin{array}{l}0.088^{* *} \\
(0.030)\end{array}$ & $\begin{array}{c}0.045 \\
(0.029)\end{array}$ \\
\hline $\begin{array}{l}\text { Average of all the DOT People } \\
\text { Skills }\end{array}$ & $\begin{array}{l}0.050 * * \\
(0.019)\end{array}$ & $\begin{array}{l}0.051 * * \\
(0.019)\end{array}$ & $\begin{array}{l}-0.003 \\
(0.019)\end{array}$ & $\begin{array}{l}0.059 * * \\
(0.027)\end{array}$ & $\begin{array}{c}0.025 \\
(0.027)\end{array}$ & $\begin{array}{c}0.009 \\
(0.028)\end{array}$ & $\begin{array}{c}0.042 \\
(0.027)\end{array}$ & $\begin{array}{l}0.076 * * \\
(0.026)\end{array}$ & $\begin{array}{l}-0.001 \\
(0.026)\end{array}$ \\
\hline $\begin{array}{l}\text { People-Task of Borghans et al. } \\
(2006)\end{array}$ & $\begin{array}{l}0.046 * * \\
(0.018)\end{array}$ & $\begin{array}{l}0.044 * * \\
(0.018)\end{array}$ & $\begin{array}{l}-0.010 \\
(0.019)\end{array}$ & $\begin{array}{l}0.058 * * \\
(0.026)\end{array}$ & $\begin{array}{c}0.022 \\
(0.026)\end{array}$ & $\begin{array}{c}0.006 \\
(0.027)\end{array}$ & $\begin{array}{c}0.035 \\
(0.026)\end{array}$ & $\begin{array}{l}0.065 * * \\
(0.025)\end{array}$ & $\begin{array}{l}-0.012 \\
(0.026)\end{array}$ \\
\hline
\end{tabular}


Panel B: Mother-Child

\begin{tabular}{|c|c|c|c|c|c|c|c|c|c|}
\hline \multirow{4}{*}{$\begin{array}{l}\text { Independent Variable } \\
\text { (Separate Regression) }\end{array}$} & \multicolumn{3}{|c|}{ Children } & \multicolumn{3}{|c|}{ Sons } & \multicolumn{3}{|c|}{ Daughters } \\
\hline & \multicolumn{9}{|c|}{ Dependent Variable } \\
\hline & \begin{tabular}{|c|} 
Sociability in \\
Early \\
Adulthood \\
\end{tabular} & $\begin{array}{c}\text { Sociability at } \\
\text { Age } 6\end{array}$ & \begin{tabular}{|c|} 
No. Clubs \\
Participated \\
In
\end{tabular} & \begin{tabular}{|c|}
$\begin{array}{c}\text { Sociability in } \\
\text { Early } \\
\text { Adulthood }\end{array}$ \\
\end{tabular} & $\begin{array}{c}\text { Sociability at } \\
\text { Age } 6\end{array}$ & \begin{tabular}{|c|} 
No. Clubs \\
Participated \\
In
\end{tabular} & \begin{tabular}{|c|}
$\begin{array}{c}\text { Sociability in } \\
\text { Early } \\
\text { Adulthood }\end{array}$ \\
\end{tabular} & $\begin{array}{c}\text { Sociability at } \\
\text { Age } 6\end{array}$ & $\begin{array}{c}\text { No. Clubs } \\
\text { Participated } \\
\text { In }\end{array}$ \\
\hline & (1) & $(2)$ & (3) & $(4)$ & (5) & $(6)$ & $(7)$ & $(8)$ & $(9)$ \\
\hline Mothers & & & & & & & & & \\
\hline Dealing with People & $\begin{array}{l}0.058 * * \\
(0.023)\end{array}$ & $\begin{array}{l}0.043 * * \\
(0.021)\end{array}$ & $\begin{array}{c}0.031 \\
(0.022)\end{array}$ & $\begin{array}{l}0.063 * \\
(0.033)\end{array}$ & $\begin{array}{c}0.044 \\
(0.031)\end{array}$ & $\begin{array}{l}0.077 \text { ** } \\
(0.032)\end{array}$ & $\begin{array}{c}0.046 \\
(0.031)\end{array}$ & $\begin{array}{c}0.040 \\
(0.029)\end{array}$ & $\begin{array}{l}-0.008 \\
(0.037)\end{array}$ \\
\hline Talking and/or Hearing & $\begin{array}{l}0.056 \text { ** } \\
(0.023)\end{array}$ & $\begin{array}{l}0.039 * \\
(0.022)\end{array}$ & $\begin{array}{c}0.034 \\
(0.023)\end{array}$ & $\begin{array}{c}0.051 \\
(0.034)\end{array}$ & $\begin{array}{c}0.030 \\
(0.033)\end{array}$ & $\begin{array}{l}0.090 * * \\
(0.034)\end{array}$ & $\begin{array}{l}0.054 \text { * } \\
(0.032)\end{array}$ & $\begin{array}{c}0.044 \\
(0.030)\end{array}$ & $\begin{array}{l}-0.007 \\
(0.030)\end{array}$ \\
\hline Communicate Data & $\begin{array}{l}0.082 \text { ** } \\
(0.024)\end{array}$ & $\begin{array}{l}0.065 * * \\
(0.023)\end{array}$ & $\begin{array}{c}0.038 \\
(0.024)\end{array}$ & $\begin{array}{l}0.089 \text { ** } \\
(0.035)\end{array}$ & $\begin{array}{l}0.061 \\
(0.033)\end{array}$ & $\begin{array}{l}0.059 \text { * } \\
(0.034)\end{array}$ & $\begin{array}{l}0.072 \text { ** } \\
(0.034)\end{array}$ & $\begin{array}{l}0.069 \text { ** } \\
(0.032)\end{array}$ & $\begin{array}{l}-0.009 \\
(0.031)\end{array}$ \\
\hline Business Contact with People & $\begin{array}{l}0.047 * * \\
(0.021)\end{array}$ & $\begin{array}{l}0.057 * * \\
(0.020)\end{array}$ & $\begin{array}{c}0.020 \\
(0.020)\end{array}$ & $\begin{array}{l}0.051 \text { * } \\
(0.031)\end{array}$ & $\begin{array}{c}0.048 \\
(0.029)\end{array}$ & $\begin{array}{c}0.038 \\
(0.030)\end{array}$ & $\begin{array}{c}0.039 \\
(0.028)\end{array}$ & $\begin{array}{l}0.064 * * \\
(0.028)\end{array}$ & $\begin{array}{c}0.019 \\
(0.033)\end{array}$ \\
\hline Work for Good of People & $\begin{array}{c}0.018 \\
(0.023)\end{array}$ & $\begin{array}{c}0.004 \\
(0.022)\end{array}$ & $\begin{array}{c}0.013 \\
(0.022)\end{array}$ & $\begin{array}{c}0.055 \\
(0.034)\end{array}$ & $\begin{array}{c}0.032 \\
(0.033)\end{array}$ & $\begin{array}{l}0.056 \text { * } \\
(0.033)\end{array}$ & $\begin{array}{l}-0.019 \\
(0.031)\end{array}$ & $\begin{array}{l}-0.020 \\
(0.030)\end{array}$ & $\begin{array}{c}0.008 \\
(0.028)\end{array}$ \\
\hline Interpret Feelings & $\begin{array}{l}-0.028 \\
(0.023)\end{array}$ & $\begin{array}{l}-0.0001 \\
(0.023)\end{array}$ & $\begin{array}{c}0.003 \\
(0.025)\end{array}$ & $\begin{array}{l}-0.005 \\
(0.031)\end{array}$ & $\begin{array}{c}0.042 \\
(0.030)\end{array}$ & $\begin{array}{r}0.030 \\
(0.039)\end{array}$ & $\begin{array}{l}-0.052 \\
(0.033)\end{array}$ & $\begin{array}{l}-0.040 \\
(0.034)\end{array}$ & $\begin{array}{l}-0.025 \\
(0.033)\end{array}$ \\
\hline Influencing People & $\begin{array}{l}0.0644^{* *} \\
(0.029)\end{array}$ & $\begin{array}{c}0.038 \\
(0.028)\end{array}$ & $\begin{array}{l}0.047 \text { * } \\
(0.028)\end{array}$ & $\begin{array}{c}0.065 \\
(0.040)\end{array}$ & $\begin{array}{c}0.039 \\
(0.043)\end{array}$ & $\begin{array}{c}0.067 \\
(0.042)\end{array}$ & $\begin{array}{c}0.060 \\
(0.043)\end{array}$ & $\begin{array}{c}0.038 \\
(0.038)\end{array}$ & $\begin{array}{c}0.036 \\
(0.038)\end{array}$ \\
\hline Relation to People & $\begin{array}{l}0.075 * * \\
(0.026)\end{array}$ & $\begin{array}{c}0.036 \\
(0.025)\end{array}$ & $\begin{array}{l}0.054 \text { ** } \\
(0.026)\end{array}$ & $\begin{array}{l}0.077^{* *} \\
(0.038)\end{array}$ & $\begin{array}{c}0.043 \\
(0.037)\end{array}$ & $\begin{array}{l}0.104 * * \\
(0.038)\end{array}$ & $\begin{array}{l}0.070 \text { * } \\
(0.037)\end{array}$ & $\begin{array}{c}0.028 \\
(0.035)\end{array}$ & $\begin{array}{c}0.018 \\
(0.035)\end{array}$ \\
\hline $\begin{array}{l}\text { Average of all the DOT People } \\
\text { Skills }\end{array}$ & $\begin{array}{l}0.068 * * \\
(0.024)\end{array}$ & $\begin{array}{l}0.053 * * \\
(0.023)\end{array}$ & $\begin{array}{l}0.043 \text { * } \\
(0.024)\end{array}$ & $\begin{array}{l}0.082 \text { ** } \\
(0.035)\end{array}$ & $\begin{array}{l}0.063 * \\
(0.034)\end{array}$ & $\begin{array}{l}0.095 * * \\
(0.036)\end{array}$ & $\begin{array}{c}0.049 \\
(0.034)\end{array}$ & $\begin{array}{c}0.044 \\
(0.032)\end{array}$ & $\begin{array}{r}0.001 \\
(0.033)\end{array}$ \\
\hline $\begin{array}{l}\text { People-Task of Borghans et al. } \\
(2006)\end{array}$ & $\begin{array}{l}0.060 * * \\
(0.026)\end{array}$ & $\begin{array}{l}0.055 * * \\
(0.025)\end{array}$ & $\begin{array}{c}0.040 \\
(0.026)\end{array}$ & $\begin{array}{l}0.084 \text { ** } \\
(0.037)\end{array}$ & $\begin{array}{l}0.075 * * \\
(0.036)\end{array}$ & $\begin{array}{l}0.098 * * \\
(0.039)\end{array}$ & $\begin{array}{c}0.029 \\
(0.036)\end{array}$ & $\begin{array}{c}0.036 \\
(0.034)\end{array}$ & $\begin{array}{l}-0.007 \\
(0.034)\end{array}$ \\
\hline
\end{tabular}




\section{Appendix Table 5: Factor Analysis for DOT Skills}

Panel A: NLSY Fathers

Factor Loadings

\begin{tabular}{|c|c|c|c|c|c|c|c|}
\hline & & & & & & & \\
\hline Variables & 1 & 2 & 3 & 4 & 5 & 6 & Uniqueness \\
\hline$\overline{\text { Data }}$ & 0.951 & -0.069 & -0.138 & -0.008 & 0.064 & 0.002 & 0.067 \\
\hline Math & 0.941 & 0.025 & -0.104 & 0.015 & -0.145 & 0.025 & 0.081 \\
\hline Reasoning & 0.937 & -0.020 & -0.199 & 0.139 & 0.036 & 0.018 & 0.061 \\
\hline Language & 0.893 & -0.163 & -0.218 & 0.238 & 0.012 & 0.058 & 0.068 \\
\hline SVP & 0.934 & 0.138 & -0.002 & -0.050 & -0.039 & -0.052 & 0.103 \\
\hline General Learning & 0.880 & -0.185 & -0.214 & 0.179 & 0.012 & 0.158 & 0.088 \\
\hline Verbal & 0.872 & -0.199 & -0.301 & 0.185 & 0.058 & -0.055 & 0.069 \\
\hline Numerical & 0.868 & 0.005 & -0.208 & 0.114 & -0.167 & -0.069 & 0.157 \\
\hline Clerical Perception & 0.659 & -0.310 & -0.451 & 0.199 & -0.013 & 0.116 & 0.213 \\
\hline Plan Activity & 0.868 & 0.131 & 0.046 & 0.168 & 0.080 & -0.203 & 0.151 \\
\hline Make Evaluations & 0.692 & -0.473 & -0.155 & -0.275 & 0.005 & 0.208 & 0.155 \\
\hline Creative Activity & 0.537 & -0.177 & 0.031 & 0.511 & 0.262 & 0.136 & 0.331 \\
\hline Esteem of Others & 0.196 & -0.613 & -0.542 & -0.165 & 0.152 & -0.039 & 0.240 \\
\hline Relation to People & 0.617 & -0.463 & -0.316 & 0.276 & 0.293 & 0.106 & 0.132 \\
\hline Dealing with People & 0.418 & -0.553 & -0.399 & 0.196 & 0.405 & -0.258 & 0.091 \\
\hline Talk and/or Hearing & 0.538 & -0.418 & -0.355 & 0.147 & 0.418 & -0.250 & 0.151 \\
\hline Communicate Data & 0.468 & -0.445 & -0.430 & 0.390 & 0.344 & -0.201 & 0.088 \\
\hline Business Contact & 0.034 & -0.498 & -0.293 & 0.003 & 0.420 & -0.530 & 0.208 \\
\hline Work for Good of People & 0.185 & -0.613 & -0.312 & 0.397 & 0.181 & -0.089 & 0.294 \\
\hline Interpret Feeling & 0.100 & -0.006 & -0.047 & 0.521 & -0.057 & 0.068 & 0.708 \\
\hline Influencing People & 0.189 & -0.360 & -0.178 & 0.729 & 0.007 & -0.241 & 0.213 \\
\hline Relation to Things & 0.083 & 0.843 & 0.340 & -0.118 & -0.029 & 0.164 & 0.126 \\
\hline Motor Coordination & -0.232 & 0.854 & 0.001 & 0.052 & 0.118 & 0.053 & 0.198 \\
\hline Form Perception & 0.593 & 0.630 & 0.016 & -0.062 & -0.017 & -0.096 & 0.237 \\
\hline Spatial Perception & 0.326 & 0.677 & 0.210 & -0.174 & 0.105 & 0.252 & 0.287 \\
\hline Finger Dexterity & 0.190 & 0.855 & 0.028 & 0.024 & -0.151 & -0.250 & 0.147 \\
\hline Manual Dexterity & -0.327 & 0.819 & 0.195 & -0.142 & 0.024 & 0.000 & 0.164 \\
\hline Eye-Hand-Foot Coord. & -0.335 & 0.252 & 0.565 & -0.066 & 0.275 & 0.369 & 0.289 \\
\hline Color Discrimination & 0.036 & 0.530 & 0.132 & 0.158 & 0.202 & 0.427 & 0.453 \\
\hline Precisely Set Limits & -0.015 & 0.752 & 0.152 & -0.242 & -0.374 & -0.234 & 0.158 \\
\hline Repetitive Work & -0.860 & -0.097 & -0.100 & -0.087 & -0.114 & 0.317 & 0.120 \\
\hline Make Judgments & 0.501 & 0.543 & 0.219 & -0.316 & -0.193 & -0.079 & 0.264 \\
\hline Perform Variety of Duties & 0.539 & 0.152 & 0.485 & -0.271 & 0.135 & -0.019 & 0.359 \\
\hline Under Stress & -0.070 & 0.041 & -0.012 & -0.046 & 0.776 & 0.029 & 0.388 \\
\hline Strength & -0.527 & 0.344 & 0.656 & -0.072 & -0.001 & 0.067 & 0.164 \\
\hline Climb & -0.064 & 0.155 & 0.870 & -0.080 & -0.090 & -0.007 & 0.200 \\
\hline Stoop & -0.292 & 0.267 & 0.823 & -0.100 & -0.089 & 0.070 & 0.144 \\
\hline Reach & -0.509 & 0.649 & 0.325 & -0.155 & -0.029 & 0.235 & 0.134 \\
\hline See & -0.061 & 0.780 & 0.185 & -0.205 & 0.135 & 0.288 & 0.211 \\
\hline & 12.457 & 8.693 & 4.464 & 2.268 & 1.923 & 1.483 & \\
\hline$\%$ of Variance & 0.319 & 0.223 & 0.115 & 0.058 & 0.049 & 0.038 & \\
\hline
\end{tabular}

Note: Definitions of DOT skill variables are described in Appendix Table 1. The factor analysis extraction method is principal component analysis, and the rotation method is varimax with Kaiser normalization. The first, second, and third factors are identified as cognitive skill, motor skill, and physical strength, respectively. While both the fourth and fifth factors are labeled as people skills, the fourth factor has a relatively higher loading on "interpret feelings" and "influence people" and the fifth factor has a relatively higher loading on "deal with people," "talking/hearing," and "business contact with people." Factor loadings in bold indicate to which factor the DOT variable was assigned. 
Appendix Table 5: Factor Analysis for DOT Skills (continued)

Panel B: NLSY Mothers

Factor Loadings

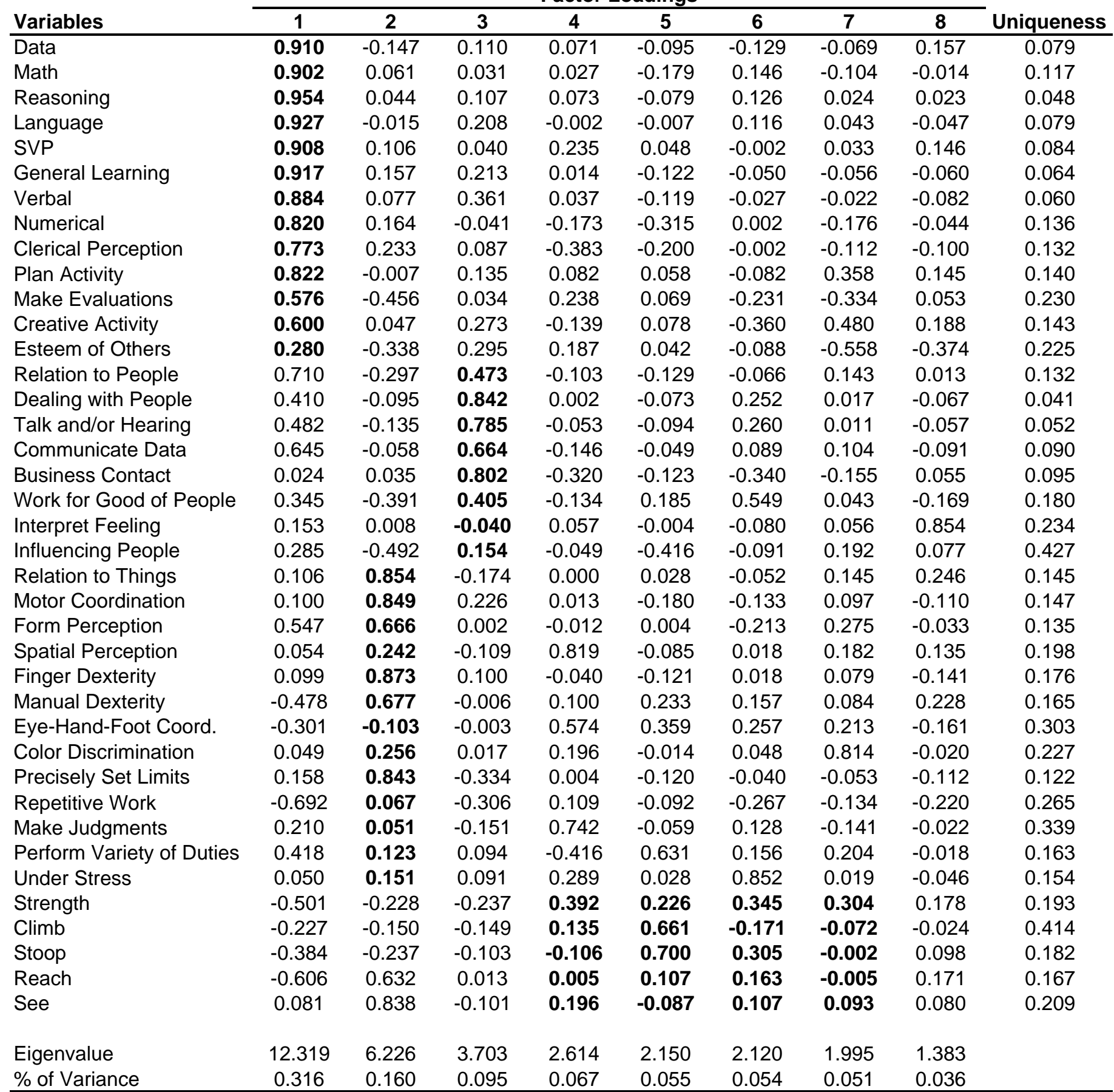

Note: Definitions of DOT skill variables are described in Appendix Table 1. The factor analysis extraction method is principal component analysis, and the rotation method is varimax with Kaiser normalization. The first, second, and third factors are labeled as cognitive, motor, and people skills, respectively. The fourth through the seventh factors are labeled physical strength. The fourth factor also has high loading on "spatial perception" and "make judgments"; the fifth factor has high loading on "perform variety of duties"; the sixth factor on "under stress"; and the seventh factor on "color discrimination." The eighth factor has a high loading only for "interpret feeling." Factor loadings in bold indicate to which factor the DOT variable was assigned. 